




\section{HEINONLINE}

Citation: 58 Ariz. L. Rev. 9012016

Provided by:

Vanderbilt University Law School

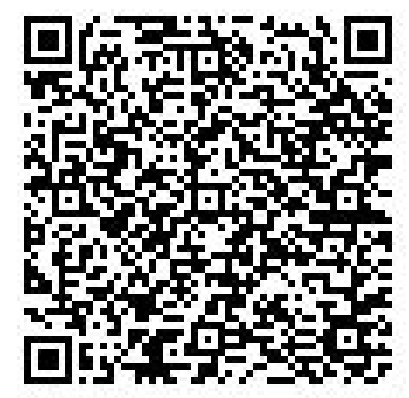

Content downloaded/printed from $\underline{\text { HeinOnline }}$

Fri Mar 31 10:29:57 2017

-- Your use of this HeinOnline PDF indicates your acceptance of HeinOnline's Terms and Conditions of the license agreement available at http://heinonline.org/HOL/License

-- The search text of this PDF is generated from uncorrected OCR text.

-- To obtain permission to use this article beyond the scope of your HeinOnline license, please use:

\section{Copyright Information}




\title{
Are College Presidents Like Football COACHES? EVIDENCE FROM THEIR EMPLOYMENT CONTRACTS
}

\author{
Randall S. Thomas ${ }^{*} \&$ R. Lawrence Van Horn ${ }^{* *}$
}

College presidents and football coaches are frequently criticized for their high compensation. In this paper, we argue that these criticisms are unmerited, as the markets for both college presidents and football coaches exhibit properties consistent with a competitive labor market. Both parties' compensation varies in sensible ways related to the size of the programs they manage, as well as their potential for value creation. Successful college presidents and football coaches can greatly increase the value of their schools well beyond the amount they receive in compensation. If these higher education executives' compensation is the result of a competitive labor market, and they do not capture compensation in excess of the incremental value they create, the overall welfare of their universities is increased.

To shed light on these issues, we engaged in a comprehensive examination and comparison of college president and football coach compensation levels and employment contracts across FBS Division I universities. We found a number of noteworthy results. First, we see large differences in job tenure of these two groups: university presidents stay in their jobs significantly longer than football coaches. Second, we observe that football coaches are paid significantly more and their pay is rising at a much faster rate than college presidents. Third, larger schools pay these top executives much more than their smaller counterparts, especially for football coaches. Furthermore, Power Five conference schools pay their coaches far more than the other football conferences. Finally, we note significant differences in the structure of the college presidents' employment contracts compared to football coaches' contracts.

For each of these major findings, we provide a detailed analysis of why they exist and how they can be explained by economic theory.

* John S. Beasley, II, Professor of Law and Business, Vanderbilt Law School, Vanderbilt University.

** Associate Professor of Economics and Management, Owen Graduate School of Business, Vanderbilt University. We would like to thank Jessica Day and Eric Shlifer for their outstanding assistance in the collection and coding of the data for this project, and Eric Shlifer again for his help in researching several aspects of the paper. 


\section{TABLE OF CONTENTS}

INTRODUCTION 902

I. ECONOMIC THEORy, Institutional FEATUREs, AND COLlEGE PRESIDENTS' CONTRACTS 907

II. COllege PREsidents: ReCRUiting, HiRing, AND NegOtiation OF

EMPLOYMENT CONTRACTS ......................................................... 913

A. Creating the Search Committee to Hire a New College President ............. 914

B. Planning the Search and Creating a Pool of Candidates........................915

C. Interviewing Candidates and Developing the Finalists .....................917

D. Picking the President ....................................................... 918

E. Negotiating the New President's Contract .................................919

F. Selecting Football Coaches..................................................921

G. Comparing College President and Football Coach Hiring Processes........ 923

III. College President vs. FoOtBall CoACH CONTRACTS ............................923

A. Data Collection and Comparison of the Samples ........................... 924

B. Comparing College President and Football Coach Compensation............ 928

1. Year-By-Year Comparisons .......................................... 928

2. Compensation Comparisons by Size ......................................... 933

3. Differences Between College Presidents and Coaches by School..........936

4. Perquisite Comparisons ........................................................937

C. Contract Length Comparisons ................................................ 940

D. Termination Provisions: With Cause and Without Cause ..................... 942

1. For-Cause Termination Clauses .............................................. 943

2. Evolution of Cause Termination Provisions ..................................947

3. Without-Cause Termination Payments.........................................952

E. Noncompetition and Arbitration Provisions ........................................ 955

CONCLUSION 956

\section{INTRODUCTION}

College presidents ${ }^{1}$ and football coaches ${ }^{2}$ are normally the highest-paid university executives. Given the current attention paid to rising college tuition, the media frequently focuses on their compensation, often arguing it is inappropriately

1. To simplify the terminology, we use "college president" to indicate the chief executive officer of a college or university. We recognize that our study includes both colleges and universities and that they may have a variety of different names for their chief executive officer. Indeed, our home university refers to its chief executive officer as its Chancellor.

2. We use the term "football coach" to refer to all of the college football head coaches that are included in our sample of FBS Division I coaches. We refer to football coaches as "he" because all of the coaches in our sample are male. 
high. ${ }^{3}$ Implicit in this claim is the belief that if a football coach or college president is paid more, then college tuition must increase, and students foot the bill. ${ }^{4}$

This view ignores two important underlying principles in executive compensation. First, the markets for both college presidents and football coaches are competitive. In a competitive labor market, highly skilled personnel can command compensation equivalent to the salaries of people in comparable positions. To attract and retain top talent in higher education, institutions must offer competitive pay packages. Failure to do so will result in losing talented executives to other schools or to jobs in other sectors of the economy.

Second, top executives in higher education control the fortunes of their programs and universities; they have the capacity to increase the value of their organization as a whole. For example, a successful football coach can boost a football program's win-loss record, which may result in significant revenues, increased publicity, and a greater number of students interested in attending the school. ${ }^{5}$ Similarly, top college presidents can create value that exceeds their total pay by turning around a flagging school or raising the value of a successful one by engaging in activities such as fundraising, grant solicitation, and development of popular academic programs. In short, so long as these higher education executives' compensation is the result of a competitive labor market, and they do not capture compensation in excess of the incremental value they create, then the overall welfare of their universities is increased.

To shed light on these issues, we examined and compared college presidents' compensation levels and employment contracts with those of football coaches at like schools. In particular, we collected data for almost all public Football Bowl Subdivision ("FBS") Division I colleges ${ }^{6}$ around the country, examining the compensation and written employment agreements of both their football coaches and their presidents. We found a number of noteworthy results that illuminate the factors affecting the executives' compensation, and how these factors align with the executives' capacity to create organizational value. First, we observed a large difference in job tenure between presidents and football coaches, which has significant implications for contracting processes and practices. We calculate that university presidents have substantially longer job tenure than football coaches: college presidents' average job tenure is about 7.6 years (median 6.0 years), whereas

3. College President's Salaries, Chron. Higher Educ. (Feb. 03, 2010), http://www.chronicle.com/article/College-Presidents-Salaries/63874 (interviewing highereducation leaders and observers about their thoughts on this issue).

4. See, e.g., LZ Granderson, Pay Coaches Less and Lower Tuition, ESPN (Nov. 18, 2011), http://www.espn.com/espn/commentary/story/_id/7252031/ (suggesting that high college coach compensation has resulted in high tuition).

5. See e.g., Monte Burke, College Coaches Deserve Their Pay, Wall St. J., Aug. 31, 2015, at A13 (referencing comments made by Mr. Witt, Alabama's president, regarding how much Coach Nick Saban has helped fundraising efforts at Alabama).

6. The NCAA is divided into three divisions, based roughly on school size; Division I is comprised of the largest schools. The FBS of Division I consists of the 128 schools that play varsity football and which are allowed to provide scholarship aid (including full scholarships) to a total of 85 players. College Athletic Scholarship Limits, ScHOLARSHIP STATS, http://www.scholarshipstats.com/ncaalimits.html (last visited Oct. 5, 2016). 
football coaches turn over on average every 4.6 years (median 3.0 years). One result of this large difference is that football coaches enter into significantly more employment contracts over our sample time period than college presidents.

This disparity reflects the underlying differences in the roles of the respective parties and the criteria for their performance evaluations. Because clear measures of success are directly attributable to the football coach, and because his success has significant financial implications for the university, the coach's job tenure should reflect his ability to create value. Keeping a coach with poor performance is costly. On the other hand, although there exist several objective measures for college president performance, some others are less clear and there is less direct connection between a president's actions and their university's overall performance. This makes it more difficult to identify and discharge poor performers.

Second, we see strong trends in compensation levels and their components in our sample period. Beginning with college presidents' total compensation, we see that during 2010-2014, five years for which we have comprehensive data, these executives' average total compensation grew from $\$ 416,343$ to $\$ 463,018$, or about $10 \%$, most of which was in the form of increases in base salary. By way of comparison, if we look at the five-year 2009-2013 timeframe for football coaches, for which we have complete data, we see average fixed pay increasing from $\$ 1,138,285$ to $\$ 1,570,823$ - approximately $38 \%$ overall. Thus we see football coach pay increasing not only much faster than college president pay but also starting at a higher average level. These pay increases are particularly noticeable at schools in the five major football conferences (SEC, Big Ten, Pac-12, Big 12 and ACC) ("the Power Five Conferences").

This is likely due to the large increase in television and bowl revenues attributable to college football at these schools. For example, in the 2014-2015 fiscal year, the Southeastern Conference ("SEC") generated $\$ 112$ million from bowl games and an additional $\$ 347$ million in TV deals. ${ }^{7}$ Each school in the SEC took home approximately $\$ 34$ million of which $\$ 8$ million was attributable to bowl games. ${ }^{8}$ The SEC has projected that, when its TV contract with ESPN is renegotiated in 2017-2018, each SEC school will receive in excess of \$44 million annually. ${ }^{9}$ While the SEC is the most highly valued conference, each team that is a member of the Power Five Conferences received in excess of \$20 million from 2014 to $2015 .^{10}$

7. Jason Alsher, 5 College Conferences That Bring in Over $\$ 250$ Million, CHEATSHEET (July 8, 2016), http://www.cheatsheet.com/sports/the-5-most-valuableconferences-in-college-sports.html/?a=viewall. This does not include $\$ 12$ million for basketball. Andy Staples, The Future of College Sports Media Rights, CAMPUS RusH (Mar. 28, 2016), http://www.campusrush.com/college-sports-media-rights-deals-punt-pass-pork1692890873.html (stating that CBS pays $\$ 12$ million annually to broadcast BIG Ten basketball).

8. Alsher, supra note 7.

9. Chris Smith, The SEC is Finally the Most Valuable Conference in College Sports, ForBes (July 20, 2015, 11:53 AM), http://www.forbes.com/sites/chrissmith/2015/07/20/the-sec-is-finally-the-most-valuableconference-in-college-sports/2/.

10. Id. 
Given the lucrative nature of college football for these schools, average coach salaries seem more reasonable.

Comparing total compensation levels among the members of both groups of top executives reveals significant disparities. By examining the pay differential for college presidents across different size institutions we found that, in 2013, the smallest quartile of universities paid their presidents an average of $\$ 386,573$ in total pay, whereas the largest quartile of schools paid their chief executive officers on average $\$ 576,734$, or almost $49 \%$ more than the smallest schools. ${ }^{11}$ Similar, but more marked, differences exist for football coaches. For example, in 2013, football coaches at the smallest quartile of FBS Division I schools earned total fixed pay of $\$ 412,832$, whereas coaches at the largest schools made total fixed compensation of $\$ 2,664,955$, or about $545 \%$ more on average than their counterparts at smaller schools.

There are likely two factors at play here. First, for college presidents, those at larger universities have a larger alumni base and thereby greater capacity to create value for the university through fundraising. ${ }^{12}$ Second, with greater size comes greater job complexity and greater job responsibilities. This suggests the need for more highly qualified personnel who command a higher labor-market premium. ${ }^{13}$ For coaches, the size effect associated with college football programs is largely due to membership in one of the Power Five conferences where, as noted above, revenue from TV and bowl appearances is significantly higher than at other schools and conferences. ${ }^{14}$ In sum, greater value creation by coaches at the larger schools leads to greater compensation.

We also generated school-by-school comparisons to see if there are intraschool variations that would help us understand the differences between college president pay and football coach compensation. We found that football coaches at the Power Five Conference programs are paid far more than coaches at the other FBS Division I schools (around four times more) and far more than all college presidents (about six and a half times more). ${ }^{15}$ By comparison, there is little difference in the total compensation paid to college presidents at the power football conferences and the college presidents at other schools in our sample. Furthermore, football coaches at non-power-conference schools are only paid around one and a half times what their home school's president is paid. ${ }^{16}$ Again, the most obvious explanation for these trends is the impact of increased television and bowl revenues for college football.

When we compared perquisite compensation forms and levels, we found some further interesting differences. For college presidents, we found that while

11. See infra Section III.B.2.

12. See Robert H. Atwell \& Jane V. Wellman, Presidential Compensation in Higher Education: Policies and Best Practices 12-13 (2000).

13. See Rajiv D. Banker et al., The Compensation of University Presidents: A Principal-Agent Theory and Empirical Evidence 14-15 (AAA 2010 Mgmt. Accounting Section (MAS) Meeting Paper, Aug. 6, 2009), http://ssrn.com/abstract=1444849.

14. Smith, supra note 9.

15. See infra Section III.B.3.

16. Id. 
home institutions provide a majority with country club memberships, a lower, but still significant, percentage are given a college-owned house to live in, as well as a car or car allowance. ${ }^{17}$ The number of university presidents receiving these perquisites has been stable or slightly declining over the past twenty years. ${ }^{18}$ By contrast, the use of perquisites for football coaches has increased sharply in recent years. ${ }^{19}$ Although football coaches are not generally provided with a house by the university, they are commonly given a car or car allowance, a country club membership, and, in a small but growing percentage of cases, the use of a collegeowned plane for personal travel. ${ }^{20}$

Furthermore, the analysis demonstrates that institutions offer perquisites that tend to correspond to resources that will facilitate the executives performing their jobs. A university president spends a significant amount of time entertaining potential donors, and, as such, a country club membership or university house facilitates his or her ability to do so. By contrast, a college football coach spends a high percentage of his time recruiting new players and is frequently on the road visiting recruits. Resources, such as a car or plane, which reduce these costs, can make the coach more effective and successful in his job.

Next, we turned to the legal terms of the two types of executive employment contracts to see if there are fundamental differences between college president employment contracts and those negotiated by football coaches. Overall, college presidents' employment contracts are much more general in their terms than football coach contracts. ${ }^{21}$ For example, football coach employment contracts are much more likely to include a fixed term of years than college presidents' contracts. $^{22}$ In the instances where a college president's contract includes a fixed term, the length of the term included in a football coach contract is likely to be significantly longer. ${ }^{23}$ College presidents' contracts have fewer defined terms that constitute grounds for for-cause termination if they engage in serious misconduct. ${ }^{24}$ In considering the legal protections of the contracts, we found that while universities have, over time, sought greater rights to terminate both groups of employees, football coach contracts have developed much stronger employer rights than college president contracts. ${ }^{25}$ This again may be attributed to the short tenure and disparities in evaluating the two positions. Finally, our analysis shows that college football coaches receive greater severance payments than college presidents if they are terminated without cause. Given the relatively short job tenure of football coaches, it is not surprising that they bargain for greater protection for their position in these circumstances. ${ }^{26}$ Ultimately, the findings of the research all provide insight that

\footnotetext{
17. See infra Section III.B.4.

18. Id.

19. Id.

20. Id.

21. See infra Section III.C.

22. See infra Table 6 (demonstrating detailed data on this comparison).

23. Id.

24. See infra Section III.D.

25. Id.

26. We also found that neither set of contracts used arbitration or noncompete clauses often. See id.
} 
college executive pay follows the underlying principles of executive compensation. The contracts demonstrate terms of a competitive labor market and a reflection of the incremental value the executives add to the organization.

This Article proceeds as follows. In Part I, we provide an overview of the implications of economic theory for college presidents and football coaches' compensation and contracting provisions. Part II contains an overview of the recruiting, hiring, and negotiation processes for college presidents' as well as a discussion about how such processes differ from those used by universities for football coaches. Part III contains our comparative empirical analysis of college presidents' and football coaches' employment contracts and compensation. In Part III's analysis, we present the detailed comparisons of compensation levels and forms, as well as the legal language of the underlying employment contracts. We finish with brief concluding remarks.

\section{ECONOMic Theory, Institutional Features, ANd COLLEge Presidents' Contracts}

The structure of an organization, the nature of its employment contracts with its employees, and the level of compensation the organization pays its employees have all been the subject of organizational, economic, and principalagent theorists for many years, dating back to the seminal work of Michael Jensen and William Meckling. ${ }^{27}$ Adopting the theoretical approach of this literature affords us the ability to predict and explain the types of contracts and compensation that appear in any employment setting. In the case of college presidents, the president's role in the university, along with certain institutional characteristics of universities, helps us make strong predictions around what is likely to be a stable and efficient form of employment.

To begin with, college presidents are both similar to and different from CEOs. Presidents serve as the public face of the university. Their primary role is to chart an aspirational vision for the future of the institution that will engage future students and past alumni. ${ }^{28}$ They reflect both the academic and cultural priorities of the institution. Like corporate CEOs, they are accountable to a board, called the board of trustees. However, while corporate CEOs are evaluated based upon simple, observable measures that reflect the profit-making objectives of the organization and financial returns to shareholders, the goals for a university president are broader and less clear. The business of higher education has not been the preferred venue of forprofit commercial enterprises. ${ }^{29}$ University presidents guide non-profit or public

27. See generally Michael C. Jensen \& William H. Meckling, Theory of the Firm: Managerial Behavior, Agency Costs and Ownership Structure, 3 J. FIn. Econ. 305 (1976).

28. See K. Johnson Bowles, The President's Many Roles, InsDE HigHER ED. (July 1, 2013), https://www.insidehighered.com/advice/2013/07/01/many-roles-and-expectationscollege-presidents-essay.

29. We acknowledge that this world is evolving, as evidenced by the likes of the University of Phoenix and other for-profit universities. Their business models face a significant backlash from the establishment and charges of profiteering at the expense of individuals wishing to improve themselves. See, e.g., Sam Dillon, Troubles Grow for a University Built on Profits, N.Y. TIMES (Feb. 11, 2007), http://www.nytimes.com/2007/02/11/education/11phoenix.html; see also Emily Hanford, 
organizations, both of which lack a profit motive as the guiding force for their existence. The lack of a profit motive makes it more difficult to evaluate the purpose or effectiveness of college presidents' actions.

Higher education has conceptually occupied a different position in society than that of the firm, one in which commercial motives are eschewed and loftier goals are pursued. Measuring success of a for-profit CEO is straightforwardshareholder return-but a college president must be evaluated relative to the sometimes ill-defined objectives of a non-profit organization. This lack of clear objectives can afford presidents great discretion in how they run their universities. Higher education is particularly challenging as it also pursues a social objective: education.

In pursuit of these multiple objectives, university presidents are frequently constrained by both the idiosyncratic preferences of the board, as well as other pragmatic limitations to pursuing the board's intent. For instance, a common practice dating back centuries allows the faculty within a university to have a role in university governance, and, by dint of the tenure process, the faculty cannot be removed by the president without cause ${ }^{30}$ Therefore, under this practice, the ability of a university president to change the culture, operations, and execution of the faculty, consistent with the objectives of the board, is limited.

More generally, university presidents are often limited by highly politicized environments, balancing often-competing constituencies. These include not only the preferences of the board of trustees or the state legislature, but also the preferences of the faculty, current students, and the alumni-who can be a key source of financial support. Taken collectively in a normative sense, it is not clear whose goals university presidents should maximize and, therefore, what objectives their employment contracts should incentivize. ${ }^{31}$ In other words, it is not evident whose preferences should dominate among the competing stakeholders: board members, state legislatures, faculty, or students. As a result, it is likewise unclear what provisions the contract for a president should include if the goal is to incentivize the president to maximize the value of the organization. For our purposes, college presidents' struggles with different goals make the analysis of their actual employment contracts revealing from a theoretical perspective.

The Case Against For-Profit Colleges and Universities, Am. Pub. Media: Am. RAdio Works, $\mathrm{http}: / /$ americanradioworks.publicradio.org/features/tomorrows-college/phoenix/caseagainst-for-profit-schools.html (last visited Sept. 18, 2016).

30. Judith Areen, Government as Educator: A New Understanding of First Amendment Protection of Academic Freedom and Governance, 97 GEO. L.J. 945, 959-60 (2009).

31. Ctr. for Policy analysis, American Council on Education, The American College President 2012, at 33-37 (2012) [hereinafter CENTER For Policy] (detailing the most important constituencies for college presidents in terms of their time allocation, and finding that legislators, faculty, and governing boards were the most demanding). 
As non-profits, universities have a decidedly different objective and governance structures than investor-owned firms. ${ }^{32}$ In the case of a non-profit firm, the objective is to pursue some goals that balance financial performance with nonfinancial social objectives. The most common form of commercial non-profit organizations are hospitals and universities. ${ }^{33}$

Under a non-profit charter, an organization is subject to the so-called "nondistribution constraint," which precludes the distribution of financial surplus to shareholders. ${ }^{34}$ To the extent that a non-profit organization generates a surplus from operations (that is, its revenues are in excess of the costs of providing the service), the president is in a position to determine the disposition of these rents. Because the non-distribution constraint requires the executives and the board to consume any available surplus within the organization, ${ }^{35}$ the constraint can create tension between the president and the board of a non-profit. Depending on the nature of the employment arrangement and the assignment of decision-making rights, college presidents will have significant latitude on how to pursue objectives that are nonpecuniary and consistent with their preferences, yet, which may be at odds with the preferences of the board of the organization. An employment contract can be a way of addressing this potential conflict.

Many universities are also public organizations. These universities, while sharing some characteristics with private non-profit universities, are the beneficiaries of state-appropriated funds and, as such, have an objective that is determined in part by their state legislatures. Public universities rely on in-state tuition, out-of-state tuition, and government-appropriated funds to pursue their operations, though they vary widely in their dependence on state funding for operations. Irrespective of the level of funding, a public university president has the additional challenge of being accountable not only to a board, but to a board that is appointed by elected officials, who likely reflect the modal preferences of the state's at-large population.

It is reasonable to assume that there exists some objective function, a combination of the preferences of the state legislature, the faculty, the alumni, and the student population, which the president "should" pursue. Given the differences among the stakeholders, however, it is likely that this is a complex function that lacks specificity. The principal-agent theory ascribes a behavioral model that is relevant in this setting. ${ }^{36}$ In short, this theory states that the principal, here the board, should contract with an agent, here the college president, to pursue the objectives of the organization. ${ }^{37}$ If the president's preferences are entirely consistent with those

32. See generally Henry B. Hansmann, The Role of Nonprofit Enterprise, 89 YALE L.J. 835 (1980).

33. Id. at 835 .

34. Id. at 873-74 (discussing how a non-profit organization is legally precluded from distributing financial returns to a controlling party; it is viewed as an issue of private inurement, or as an excess benefit transaction, and is a criminal offense).

35. Id.

36. Jensen \& Meckling, supra note 27, at 308.

37. PaUl MLlgrom \& John Roberts, ECONOMics, Organization AND MANAGEMENT 126-27 (1992) (discussing how parties use compacts to recognize mutual interests and "agree to modify their behavior in ways that are mutually beneficial"). 
of the board, the contract is simple. Given the preceding discussion, however, it is highly unlikely that any college president will have preferences that exactly match those of all of the constituencies that are involved with a public university. To the extent there is a divergence in these preferences, the existence and form of the contract becomes even more important as a mechanism of addressing it.

A complete contract can provide the necessary clarity and direction for a university president. The goal of a complete contract is to specify the actions of the president under all alternative states of the world in order to incentivize both the effort level and decisions that are consistent with the preferences of the organization. ${ }^{38}$ This is facilitated by a number of key factors, including clearer objectives and measurable output. If it were possible to contract with the president regarding only the performance of the university, the contract would be simple and specific. But it is costly to write a complete contract in the presence of uncertaintyboth in terms of states of the world as well as ambiguity around intent and objectives. ${ }^{39}$ There is a tradeoff between the costs and benefits of writing a complete contract. For example, most individuals are risk averse, desiring certainty over risk ceteris paribus. These individuals require a risk premium to compensate them for uncertainty. ${ }^{40}$ Given the uncertainty around objectives, outcomes, and the contractibility around effort in the case of public university presidents, written formal contracts may not exist or may be very difficult to draft.

Contracts are also an effective sorting mechanism. If it is possible to write a contract with performance rewards for employment a priori, then only those individuals who will excel under the contract will choose to seek employment. This feature encourages individuals to sort and reveal private information about their human capital and value-creating capacity around the terms of the contract. ${ }^{41}$ Hence, if it is possible to write a contract that is complete, aligned with the objectives of the firm, and predicated on realized performance whereby candidates reveal their human capital, then efficiency will be enhanced. ${ }^{42}$ Individuals will sort based on their capacity to excel under the contract that maximizes their personal benefit.

Firms also look to the employment relationship to maximize their benefits. They have differing needs based on their organizational models and types of businesses. Organizations attract labor through a combination of job attributes, compensation, and benefits. In well-functioning, competitive labor markets, the level of compensation is determined by the market. ${ }^{43}$ Individuals are endowed with different abilities to be productive and create value in firms. They must sort across organizations and match with those firms whereby they can create the greatest value.

38. Id. at 127; see, e.g., Bowles, supra note 28 (describing the many things that can and do happen during a President's tenure including terrorist attacks, man-made and natural catastrophes, and other difficult-to-predict events).

39. Milgrom \& RoBerts, supra note 37, at 130 (discussing how difficult it is to factor improbable contingencies without comparative experiences, and how high the opportunity costs are to spend time calculating such contingencies).

40. Id. at $187-88$.

41. Id. at 330 (stating that complete contracting is impossible).

42. See id. at 341

43. See Robert S. PINDyck \& Daniel L. RubinfiEld, Microeconomics 516-18 (6th ed. 2005) 
Firms and employees exist in an equilibrium; no firm can pay an employee more than the incremental value that the employee creates by joining the organization. ${ }^{44}$ As such, barring market inefficiency, the observed compensation of the university president or football coach should reflect their partial capture of the value they create. ${ }^{45}$ In cases where the institutional value created is large, readily observable or quantifiable, largely the result of the individual's efforts, and general in nature (such that the individual could generate similar performance in another institution), then we would expect the individual in question to receive higher compensation. ${ }^{46}$

Not all investments will lead to an increase in market value. An individual brings to the firm their own knowledge and experience. ${ }^{47}$ They apply these skills within the context of the organization to create value for the firm. If success requires significant knowledge of the internal workings of the firm, they will have to make an investment and incur costs to generate value. This is referred to as firm-specific human capital. ${ }^{48}$ By definition, this knowledge is specific to the firm and the particular employment relationship, and it is not valuable outside of the current employment. Because labor markets determine compensation, and firm-specific human capital is not valuable outside the current job, the market value of the individual will not increase through such investments, as they are not portable to another firm. ${ }^{49}$

Given this theoretical background, we generated a number of expectations for our research. As we have discussed in prior work, college football coaches' human capital embodies the characteristics of being general in nature and largely a function of their efforts. ${ }^{50}$ The performance of the football program is summarized by their win-loss record. The head coach has a significant impact on that performance, ${ }^{51}$ and successful coaches can readily change colleges and transfer their

44. Id.

45. Some commentators have argued that markets for corporate executives are malfunctioning because in the corporate setting, the board of directors, which sets executive pay levels, may have been unduly influenced by the executives themselves. See generally Lucian Bebchuk \& Jesse Fried, Pay Without Performance: The Unfulfilled Promise OF EXECUTIVE COMPENSATION (2004). Similar types of claims could be made about the board of trustees, which sets top executive officer pay at universities. But see Mitchell Langbert \& Marc Fox, The Compensation and Benefits of Private University Presidents 9 J. ACAD. ADMIN. HIGHER EDUC. 45, 49 (2013) (finding no evidence that "private college presidents are able to extract rents through their ties to boards of trustees").

46. Gary Becker, Human Capital: A Theoretical and Empirical analysis, With SPEClal REFERENCE TO EDUCATION 29-54 (3rd ed. 1993).

47. MILGROM \& RoBERTS, supra note 37, at 328.

48. Id.

49. $I d$.

50. Randall S. Thomas \& Larry Van Horn, College Football Coaches' Pay and Contracts: Are They Overpaid and Unduly Privileged?, 91 IND. L.J. 189, 196 (2016).

51. E.g., Mark Inabinett, Nick Saban by the Numbers: Alabama's Coach at No. 1 After 20 Seasons, AL.COM (Jan. 15, 2016, 8:18 PM), http://www.al.com/sports/index.ssf/2016/01/nick_saban_by_the_numbers_alab.html (stating that Coach Nick Saban has had success with two different college programs). 
skills to other settings. ${ }^{52}$ At the same time, overall football revenues from television contracts and bowl games have become significant and more lucrative over time. Taken collectively, these factors imply that the total compensation for football coaches should be increasing, and their employment contracts should each include a significant pay-for-performance component in terms of both compensation and job retention. Football coach contracts exhibit these features. ${ }^{53}$

Contrast the football coaches' task environment with that of college presidents. Universities do not have a win-loss record. While fundraising, graduation rates, rankings, and new program growth all reflect on the institution and are to some extent factored into performance evaluations that boards of trustees periodically provide to college presidents, ${ }^{54}$ they do not fit together nicely into a single definition of successful performance. Further, the primary engine of the university's academic mission is its faculty. The ability of the president to fundamentally change or affect the faculty is limited structurally through faculty governance and tenure. ${ }^{55}$ Finally, the preferences of alumni and other key stakeholders impact the definition of success. Although, the college president may influence these preferences, they are likely exogenous factors that are relatively fixed. Finally, it may be difficult to determine how much the efforts of the college president contribute to the accomplishment of the university's goals.

Given that the definition of success is unclear, the ability of the president to affect success is diffuse. Further, given that the university president embodies institution-specific knowledge and experience that limits marketability, we expected that university presidents would have lower compensation and lower pay growth over time when compared to football coach compensation. ${ }^{56}$ In other words, the outside employment options for a university president are much fewer than for a college football coach, given that a presidency frequently requires significant nontransferable investments in the university. In addition, considering the complex nature of university governance, the relationship between the president and the performance of the university is attenuated. It is difficult for any prospective university to establish the marginal contribution of a presidential candidate to the performance of the institution and, as a result, it is more difficult to support a high valuation of their contribution.

\footnotetext{
52. See, e.g., Urban Meyer, Оніо Sт., http://www.ohiostatebuckeyes.com/sports/m-footbl/mtt/meyer_urban00.html (last visited Nov. 13, 2016) (stating that the Buckeyes are Meyer's fourth team).

53. See Thomas \& Van Horn, supra note 50, at 216-20.

54. See, e.g., Amendment to Letter of Appointment Between the Bd. of Supervisors of the Univ. La Sys. and James Cofer, President Univ. of La. at Monroe (Aug. 29,2008 ) (on file with author).

55. See Areen, supra note 30.

56. Save a few notable examples of college presidents who have successfully held the post at multiple institutions. See, e.g., Linda Harris, WVU President E. Gordon Gee Has Been Giddy to Return, ST. J. (July 26, 2014, 5:00 AM) http://www.statejournal.com/story/26105216/full-circle-wvu-president-e-gordon-gee-hasbeen-giddy-to-return-to-the-post-that-launched-his-career (stating that Gee had been president of West Virginia University, the University of Colorado, and Ohio State University).
} 
We further expected college presidents to have less-complete contracts and a greater percentage of at-will employment relationships. University presidents lack a clear win-loss metric for success. Depending on the objective of the university and the perspectives of the board, university success may include growth, reputational enhancement, and improvement in national rankings, grant funding, faculty recruitment, financial performance, fundraising, and athletic performance. The relative weights that might be placed on these measures are not clear and are likely to vary from university to university. In addition, the potential for the president to affect many of these metrics in the short term is limited. In total, a contract that clearly quantifies metrics for success is difficult to write, given the likely differing views amongst the stakeholders. As such, it is more common for the board to qualitatively evaluate the performance of the president based on the members' collective opinion. This affords the board flexibility in evaluating the president and allows them to consider dimensions that do not lend themselves to direct measurement.

These four factors also have implications for contract terms regarding termination. For football coaches, given the direct relationship between on-field performance and the skills of the coach, losing is costly. It not only markedly increases the chance of termination, but also reduces the likelihood of future employment as a head coach. To compensate for this risk, college football coach contracts often include significant severance payment provisions. ${ }^{57}$

The situation is much the opposite in the case of university presidents. The inability to fully define what constitutes poor performance, coupled with a relatively tenuous relationship between the president's effort and the school's performance, militates against imposing a significant reputational cost for termination. They also have, in most cases, a fallback faculty position if they leave the presidency, as it is common for the president to return to the faculty upon completion of a term appointment. ${ }^{58}$ Accordingly, we would expect severance payment provisions to be much less common in the case of college presidents.

\section{College Presidents: Recruiting, Hiring, ANd NEGOTIATION OF EMPLOYMENT CONTRACTS}

In recent years, the process of locating and hiring a new college president has become increasingly formalized. ${ }^{59}$ In this section, we give a broad overview of

57. See Will Hobson \& Steven Rich, College Sports' Fastest-Rising Expense: Paying Coaches Not to Work, WASH. PosT (Dec. 13, 2015), https://www.washingtonpost.com/sports/colleges/college-sports-fastest-rising-expensepaying-coaches-not-to-work/2015/12/10/ec856b42-9d33-11e5-bce4708fe33e3288_story.html.

58. Charles B. NefF \& Barbara Leondar, Presidential Search: A Guide to the Process of Selecting and Appointing College and University Presidents 79 (1992).

59. The search process has been documented in a series of influential books published by the Association of Governing Boards of Universities and Colleges (the "AGB"), which are updated every few years to reflect changes in the marketplace and to reflect evolving best practices. Some recent examples include NEFF \& LEONDAR, supra note 58 and Joseph S. Johnston, JR. \& James P. Ferrare, A Complete Guide to Presidential SEARCh 
the different stages in recruiting, hiring, and negotiating the contract for new college presidents, highlighting the most important issues along the way. We then compare it to the process used for football coaches and note the important differences.

\section{A. Creating the Search Committee to Hire a New College President}

The board of trustees ("the Board") sits at the top of the organizational hierarchy at major colleges and universities. ${ }^{60}$ The Board, often consisting of influential alumni that have made major financial contributions to the school, ${ }^{61}$ is therefore vested with the ultimate decision of whom to select when an incumbent president steps down and a new president must be appointed. ${ }^{62}$ While the Board has final control over the selection of the president, there are a number of other important constituencies that will expect to be part of the process and, in most circumstances, will be included as part of the process to ensure organizational harmony. It is therefore common for the Board to set up a search committee (the "Search Committee") and to include amongst its members representatives of the faculty, students, alumni, administrators, as well as a few trustees. The goal is for all of the important players to buy into the process and to support the successful candidate once the selection is made. While the size of the committee varies, usually it contains between nine and fifteen members, which is enough to allow for a wide spectrum of views without creating too large a group to be efficient. ${ }^{63}$

The Board gives a clear charge to the Search Committee about its mandate. For example, the Board is likely to instruct the Search Committee about the appropriate number of finalist candidates to recommend to the Board at the end of the process. ${ }^{64}$ Typically, the Board will ask for three to five highly qualified finalists so that it can make a choice among them. ${ }^{65}$ The Search Committee generally will follow these instructions. Providing only one name to the Board effectively deprives the Board of making its choice in the matter. ${ }^{66}$

Next, the Board and Search Committee define what they consider to be the necessary qualities of the appointee ${ }^{67}$ College presidents perform many different

FOR UNIVERSITIES AND COLLEGES (2013). We draw on these volumes frequently in this section to provide background factual information about the college president search process.

60. See JoHnston \& FERRARE, supra note 59, at 1-2 (stating that boards "establish[] the [university's] mission and approv[e] its strategic plan, ensuring fiscal integrity and academic quality, and preserving institutional autonomy and academic freedom").

61. See, e.g., University of Michigan Board of Regents, REgENTS, http://www.regents.umich.edu/about/bios/ (last visited Nov. 4, 2016) (linking to biography pages of the eight members of the Board of Regents, seven of which are alumni).

62. JOHNSTON \& FERRARE, supra note 59, at 1 (explaining that in American higher education, the legal responsibility to select a president is borne solely by the Board).

63. NEFF \& LEONDAR, supra note 58, at 3-5.

64. Id. at 9 .

65. $I d$. at 59 .

66. Id. at 73-75. When only one president is recommended by the committee, the Board must ratify or reject the recommendation. If it rejects the recommendation, the Board must request more recommendations or create a new committee. This can be avoided if the Board charges the Search Committee to recommend two to three candidates. $I d$.

67. See Timothy L. Channell, Presidential Succession Planning for Governing Boards in Higher Education 35-36, MARSHALl Digital SCHOLAR: THESES, DisSERTATIONS 
functions, each of which may require different skill sets. ${ }^{68} \mathrm{~A}$ small, underfunded college may need someone whose specialty is fundraising, whereas a large, complex university may need a president that has more substantial administrative experience. Carefully defining the desired skill set makes the Search Committee's job more successful. ${ }^{69}$

A third important issue relates to the responsibilities of the Search Committee. ${ }^{70}$ Generally, the Search Committee will be charged with generating a pool of potential candidates, creating dossiers on each of them, and then screening them to determine the most qualified. ${ }^{71}$ The searching and screening functions can be performed by one committee, although sometimes two committees are set up, and the two functions are split between them. ${ }^{72}$

A closely related issue is whether to employ an outside search consultant, such as an executive search firm, to assist the Search Committee in assembling and screening a pool of potential candidates. Increasingly, such consultants are hired to help the Search Committee. ${ }^{73}$ While their services can be very valuable, they are costly: typically, they charge $30-33 \%$ of the first year's salary and benefits of the appointee, or if they are a non-profit, they may charge a flat fee. ${ }^{74}$ Outside consultants may be particularly useful if the college is "in a crisis situation where the institution has had two or more presidents in rapid succession, where the departure of the previous president was stormy, or where feelings of distrust and antagonism affect the attitudes of faculty, students, and trustees."75

A final preliminary issue is whether the Board will appoint an interim president immediately in order to give the search committee enough time to proceed appropriately. This decision will depend on the particular circumstances surrounding the departure of the former president: an unexpected dismissal or abrupt resignation may surprise the Board and dictate the appointment of an interim president. A failed initial search will also likely lead to the appointment of an interim candidate to provide the Board time to restart the process. ${ }^{76}$

\section{B. Planning the Search and Creating a Pool of Candidates}

One of the first things that the Board needs to do is to appoint a chair for the Search Committee. In addition to running the committee internally, the chair will

\footnotetext{
\& CAPSTONES (Jan. $\quad 1, \quad$ 2013), http://mds.marshall.edu/cgi/viewcontent.cgi?article=1469\&context=etd (listing as leadership skills "expanded self-awareness; an ability to clarify expectations, set directions, and chart a course; a talent for developing others as leaders; credibility; influence; and motivation").

68. See id. at 10-12.

69. See NEFF \& LEONDAR, supra note 58, at 15-19.

70. See id. at 3 .

71. Id. at $33-41$.

72. Id. at $3-4$.

73. See Center For Policy, supra note 31, at 45 ("Overall, 56 percent of 2011 presidents were recruited with the assistance of a search consultant.").

74. NEFF \& LEONDAR, supra note 58, at 10; see also Channell, supra note 67, at 27 ("[C]osts to institutions [for search firms run] into five and six figure dollar amounts.").

75. NEFF \& LEONDAR, supra note 58, at 11.

76. See JoHnston \& FERRARE, supra note 59, at 26.
} 
be the primary liaison between the school and the candidates. Having an experienced, well-organized chair is critical to the success of the search. ${ }^{77}$ Once the chair is in place, and the remainder of the Search Committee has been appointed, the committee needs to create a search plan with a realistic timetable. Given the broad nature of the Search Committee's work, a reasonable timeframe for the entire process to be completed is usually four to six months. ${ }^{78}$

At this point, the Search Committee can begin its job. A crucial first step is to ensure that the members of the committee are aware of the importance of preserving confidentiality. ${ }^{79}$ There are some legal limitations that bear on this issue, especially at state universities, and the Search Committee will need to comply with them carefully to avoid confusion and mistakes. ${ }^{80}$ The committee members must be aware of the rules that apply to their search. ${ }^{81}$

At this point, the Search Committee can begin a comprehensive search for candidates. ${ }^{82}$ In the early stages, the committee will cast a wide net using a variety of techniques to generate a list of potential candidates. A common method includes announcing the vacancy to the appropriate media, such as the Chronicle of Higher Education. ${ }^{83}$ The Search Committee may also decide to advertise the commencement of the school's search process and invite outside applications. ${ }^{84}$ The committee is likely to request that all of the various constituencies of the college submit the names of possible candidates that they wish the committee to consider. ${ }^{85}$ This is one area where the committee may productively employ an executive search firm to come up with lists of potential candidates. ${ }^{86}$

The best candidates may already be employed in high-level administrative positions at other colleges or universities. ${ }^{87}$ These potential candidates are often reluctant to apply for positions and may need to be courted by the Search Committee privately so as to preserve the confidential nature of their interest. ${ }^{88}$ Internal candidates also raise confidentiality issues: if internal candidates are allowed to

\author{
77. See NEFF \& LEONDAR, supra note 58, at 21. \\ 78. See id. at 30 . \\ 79. See id. at 25-26. \\ 80. See id. at 25. \\ 81. See JoHnStON \& FerraRe, supra note 59, at 57. \\ 82. Id. at 77 \\ 83. See, e.g., Presidential Openings, Chron. Higher Educ.: ViTAE, \\ https://chroniclevitae.com/job_search?job_search\%5Bposition_type $\% 5 \mathrm{D}=148$ (last visited \\ Oct. 5, 2016) (listing presidential openings). \\ 84. JOHNSTON \& FERRARE, supra note 59, at 79. \\ 85. Id. at $80-81$. \\ 86. But see Milton Greenberg, You Don't Need a Search Firm to Hire a President,
} Chron. Higher. Educ. (Sept. 1, 2014), http://chronicle.com/article/You-Dont-Need-aSearch-Firm/148525/ (stating that the use of search firms to find potential presidents has increased, but that there is no evidence that use of a search firm is beneficial).

87. JOHNSTON \& FERRARE, supra note 59, at 81.

88. NEFF \& LEONDAR, supra note 58, at 37; see, e.g., Dennis M. Barden, Inside a Presidential Search, CHRON. Higher Educ. (June 16, 2014), http://chronicle.com/article/Inside-a-Presidential-Search/147083/ (suggesting that some sitting presidents would not have entered Marquette's presidential search if it were not confidential). 
apply and the confidentiality of their application is compromised, the outside candidates may infer that the search process has been structured to favor the insider's candidacy. ${ }^{89}$ This may inhibit highly qualified outsiders from applying for the position, especially if they are already employed at other institutions. ${ }^{90}$ Generally speaking, about two-thirds of college presidents are external hires. ${ }^{91}$

\section{Interviewing Candidates and Developing the Finalists}

The Search Committee will look at the candidate pool in its entirety in a relatively short period of time. ${ }^{92}$ This must be done systematically. One possible schedule is to divide the review into phases. In phase one of the search process, the Search Committee produces a large list (15-25) of potential candidates. In the second phase, the Search Committee will promote 8-10 semifinalists to the final phase, during which the 3-5 candidates that will be submitted to the Board are selected..$^{93}$

In phase one, the Search Committee will need to read and rate the dossiers of all of the candidates. If an executive search firm is employed, the Search Committee can delegate some of the initial review and rating to them. This part of the process is designed to assemble fairly complete files that include all relevant public information about each candidate. There will be no reference checks conducted nor interviews scheduled for candidates at this early stage in the process; those will be delayed until the screening process reduces the list to the semifinalists. ${ }^{94}$

Phase two is designed to select a group of semifinalists who will be invited to interview with the Search Committee. ${ }^{95}$ Ideally, the interview team will be comprised of the entire committee, although scheduling difficulties and confidentiality may require the use of smaller subsets of the entire committee. At these interviews, the individual members of the committee are generally assigned topics on which to focus during the course of the interview. Interviews normally address the leadership areas that were included in the search mandate and last two to three hours. ${ }^{96}$

The end goal of the phase two process is the generation of a list of three to five finalists. After the completion of the interviews, the Search Committee, with the approval of the finalists, will engage in reference checks. ${ }^{97}$ These are commonly done via phone by members of the Search Committee and cover an agreed set of issues asked by designated questioners. ${ }^{98}$ An executive search firm may also be

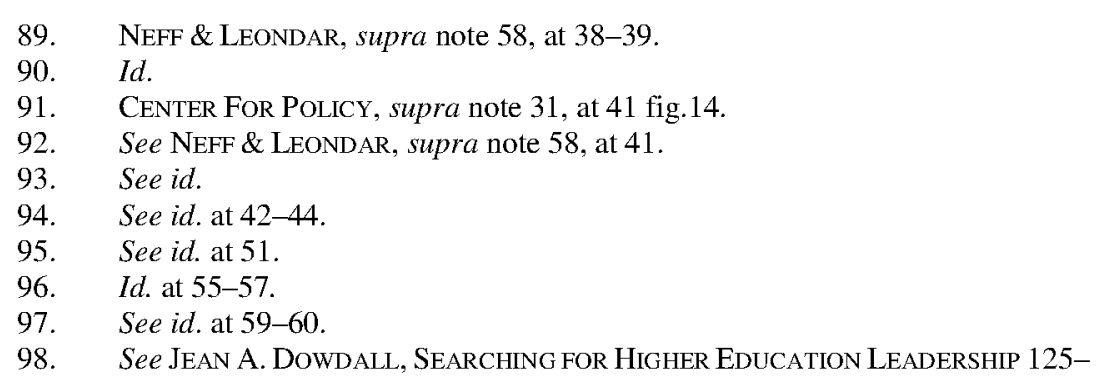


tasked with conducting background checks on the finalists. ${ }^{99}$ Throughout this process, the Search Committee must keep written records of all oral communications and stay in touch with candidates. ${ }^{100}$

Each finalist will need to visit the college campus to meet with the different university stakeholder groups, including faculty, students, administrators, and trustees. These visits generally last one-and-a-half to two days. ${ }^{101}$ At this stage, the Search Committee chair will need to discuss with each finalist candidate the general terms of employment the university will offer. This usually includes the range of total compensation that is contemplated in addition to any special terms unique to the candidate. These discussions ensure that the candidate is aware of and accepts the financial terms of the position prior to an offer being extended. At the end of their visits, the Search Committee chair generally asks each candidate if he or she is still interested in being selected for the position to make sure they are still seeking the position. ${ }^{102}$

\section{Picking the President}

Next, the Search Committee will send its list of finalists to the Board ${ }^{103}$ As noted earlier, the committee will normally provide the Board with a slate of potential candidates, rather than a single candidate, so that the Search Committee does not undermine the Board's ability to choose a preferred candidate. ${ }^{104}$ The Board will review all of the information provided by the Search Committee as well as the information it has gathered in making its decision. ${ }^{105}$ At this point, time is short, and the Board must move quickly before any of the candidates drop out of the pool. ${ }^{106}$

When it believes that it is ready to act, the decision is normally made by the entire Board. ${ }^{107}$ The Board will need to negotiate the terms of appointment for the president, including salary and pension; medical, health, and life insurance; moving expenses; housing (including maintenance and repairs); entertainment expenses; household help; and car and travel expenses. ${ }^{108}$ Many candidates will want to be awarded tenured appointments, not only because they want to teach or receive recognition of their academic achievements, but also in order to have a fallback position if they decide to retire or are fired. ${ }^{109}$

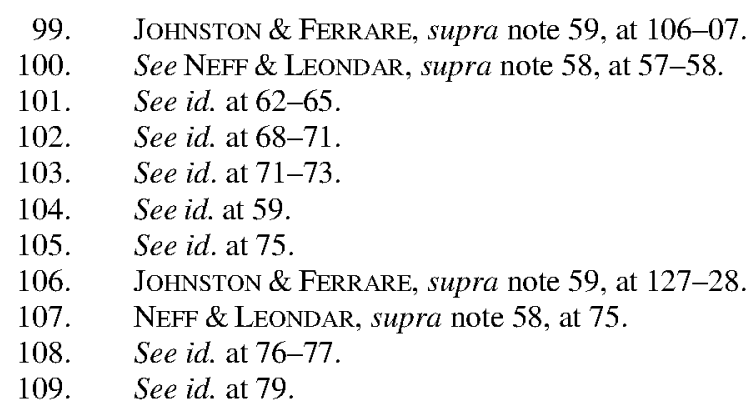




\section{E. Negotiating the New President's Contract}

In the not too distant past, a surprisingly high percentage of college presidents did not have written employment contracts. ${ }^{110}$ Those who did have written agreements had simple letter agreements from the chair of the Board. ${ }^{111}$ But as we demonstrate in Part III, this is no longer true. ${ }^{112}$ Now, not only do almost all college presidents have formal written employment contracts, but "they are beginning to look more like a corporate contract might look." 113 What are new presidents likely to see contained in their employment contracts? "The agreement between the [B]oard and the new president should be recorded in a formal, written document that systematically outlines, at a minimum, duties, terms of service, direct and indirect compensation, arrangements for performance assessment, review of compensation, and termination criteria." 114

In recent years, more contracts are heavily negotiated, complex documents. ${ }^{115}$ The increased use of written employment contracts has increased the complexity of those contracts and the use of outside counsel. ${ }^{116}$ Board chairs increasingly rely on outside advisors, such as search consultants, the university's internal legal counsel, and even specialized attorneys that are experts in tax and the negotiation of employment contracts. College presidents also talk to others, such as attorneys and colleagues in the field, to get advice on negotiating strategy. ${ }^{117}$

Contract length and compensation levels are important negotiated terms. Contract length is increasing, according to one source, which found that the most common contract length in 2011 was three years. ${ }^{118}$ Compensation levels have also increased. ${ }^{119}$

In terms of how compensation levels are set, "At most colleges, a president's salary is set after consideration of five leading factors: the size and

110. ATWELL \& WELLMAN, supra note 12, at 35 ("Almost half of the institutions in both [private and public] sectors report that they have no compensation or employment contracts ...."); see NEFF \& LEONDAR, supra note 58, at 82 ("What is really surprising is the number of institutions where the agreement is entirely oral.").

111. NEFF \& LEONDAR, supra note 58, at 82.

112. CENTER FOR POLICY, supra note 31, at 46 tbl.25 (showing a steadily increasing percentage of college presidents have written employment contracts and that by 2011 about $76 \%$ had them).

113. Janel Davis, \$1 Million Salaries for College Presidents Spur Debate, AtLANTA J.-Const. (June 9, 2015, 1:57 PM), http://www.myajc.com/news/news/localeducation/1-million-salaries-for-college-presidents-spur-deb/nmXwG/ (quoting Professor James Finkelstein).

114. JOHNSTON \& FERRARE, supra note 59, at 129.

115. Id. at 130 ("[N]egotiations sometimes produce elaborate documents that detail agreements about all aspects of the employment relationship.").

116. See id. "With the ascendance of written employment contracts, both institutions and presidential finalists are more likely to seek advice from third parties.")

117. Id.

118. CENTER For Policy, supra note 31, at 47. This is not consistent with our findings based on more recent data. See infra Table 6 and the discussion of its findings in Part III.

119. See infra Table 2a and the discussion of our findings in Part III. 
complexity of the institution, overall years of experience and talents of the president, performance in office (meeting goals and expectations), whether the school is independent or state financed, and competitive market forces." 120 Externally recruited presidents are paid more than internal candidates. ${ }^{121}$

Virtually every institution seeks to pay competitive compensation levels for their top executives, even as executive compensation has become a sensitive topic in higher education. ${ }^{122}$ Federal tax law, especially the IRS intermediate sanction requirements, require boards of 501(c)(3) institutions to avoid paying "excess benefits" in their salary and benefit payments to employees. However, these rules are designed to address board policies and procedures for setting compensation, rather than the compensation levels themselves. By following appropriate procedures, boards can ensure that the IRS rules create a rebuttable presumption that the salaries and benefits they pay are reasonable. In particular, these rules require that a delegated committee comprised solely of disinterested trustees makes compensation decisions, that compensation is benchmarked against comparable institutions, and that compensation decisions follow board reviews of presidential performance. ${ }^{123}$

As a result of these rules, and as a matter of good practice, contract provisions providing for periodic performance assessments need to be included in the president's employment contract. ${ }^{124}$ These usually "include both annual evaluations and comprehensive reviews every four or five years. ${ }^{125}$ In 2011,87 percent of college presidents had "contracts that call[ed] for annual performance evaluations conducted by boards or board subcommittees ( 60 percent), system heads (20 percent), or board chairs (14 percent)." Similar data is not available concerning the frequency of comprehensive multi-year performance reviews. ${ }^{126} \mathrm{We}$ were unable to obtain much information about these reviews for our study.

Benchmarking of compensation levels is also quite common. The "intermediate sanction regulations strongly suggest a focus on peer institutions, those that would generally be considered closely comparable in terms of control (public or independent, for-profit or not), enrollment, endowment, and other such variables." 127 At larger schools, compensation consultants are often hired to assist the board in making the appropriate comparisons. These organizations can collect, aggregate, and contextualize reliable data, and frequently maintain proprietary databases for this purpose. ${ }^{128}$

Today, more college presidents earn over $\$ 1$ million more in salary than in years past. ${ }^{129}$ This may reflect increasing value created by college presidents over

120. College Presidents Salaries, supra note 3.

121. Langbert \& Fox, supra note 45

122. See Davis, supra note 113.

123. JOHNSTON \& FERRARE, supra note 59, at 134.

124. Id. at 132 .

125. Id.

126. Id. at $132-33$.

127. Id. at 135 .

128. Id. at $135-36$.

129. Davis, supra note 113. 
time or the greater level of competition to attract top talent. Benchmarking of compensation levels explains some of this increase, as college presidents can compare their pay packages with their counterparts at other institutions. ${ }^{130}$ In the words of one commentator: "It's not unlike coaches who have a winning season . . . They keep close tabs on each other, and the salaries keep going up."131

\section{F. Selecting Football Coaches ${ }^{132}$}

FBS Division I universities need to find replacement football coaches, on average, every 4.6 years. ${ }^{133}$ Given the financial significance of college football programs at most of these schools, and the frequency with which they need to find new coaches, the hiring process has become highly professionalized. ${ }^{134}$

The athletic director ("AD") of the university will, in conjunction with an executive search firm, generate a list of potential candidates for the position. ${ }^{135}$ The search process must move quickly to ensure that the school secures a coach after the college bowl games are completed and before the athlete recruiting process for the following year begins. ${ }^{136}$ If the school is too slow, it risks losing an entire year of potential recruits. ${ }^{137}$

The search firm will act on behalf of the school to transmit preliminary information about the position to prospective candidates, while also obtaining publicly available information about each of the potential hires. ${ }^{138}$ Almost all potential candidates are employed by another football program, either as head coaches or as assistant coaches; rarely will a school hire an internal candidate. ${ }^{139}$ Many coaches employ agents to act as their intermediaries in these early discussions with search firms. ${ }^{140}$ The agent will negotiate many of the key points of a potential

130. Id. ("[C]ollege presidents closely watch how much their colleagues make.").

131. Id.

132. For an in-depth discussion of all of the steps in the process of hiring a football coach, see generally Thomas \& Van Horn, supra note 50.

133. $\quad I d$. at 215 .

134. See generally id. at 204-09.

135. Id. at $205-06$.

136. Id. at 205.

137. $I d$.

138. See Dana O'Neil, Need a Coach? There's a Firm for That, ESPN (Aug. 2, 2013), http://espn.go.com/mens-college-basketball/story/_id/9524814/search-firms-takelead-filling-head-coaching-vacancies-college-athletics.

139. One reason why internal candidates are rare is that assistant coaches' successes are very visible to other schools, and the hiring interval is very short for head coaches, so top quality "heir apparents" often get snapped up by other schools. For example, James Franklin was an assistant coach at the University of Maryland, where he had been anointed the likely successor for the head coaching position. However, when Vanderbilt University needed to hire a new head football coach, they succeeded in luring him away. See Jeff Barker, Friedgen's Firing Was Weeks in the Making, BALTIMORE Sun (Dec. 21, 2010), http://articles.baltimoresun.com/2010-12-21/sports/bs-sp-terps-fridge-1221-

20101220_1_lame-duck-atlantic-coast-conference-coach-football-coach.

140. Thomas \& Van Horn, supra note 50, at 206-07. 
employment contract, such as compensation levels, football program resources, staff levels and pay. ${ }^{141}$

Once the search firm has completed its initial process, the potential coach hires will need to request permission from their own ADs in order to talk with prospective employers. ${ }^{142}$ By this point in the search, the search firm, in consultation with the hiring school's AD, will have prepared a memorandum of understanding ("MOU") that embodies all of the basic economic terms of the proposed position: salary, contract length, perquisites, bonus pay, service pay, termination benefits, and contract buyout amounts. ${ }^{143}$ A select group of prospective candidates will be provided with this document and invited to initial interviews. ${ }^{144}$

These initial interviews are held off-campus with the intention of narrowing the pool of applicants to a small number of serious candidates, who will be invited to come to the hiring school's campus for final interviews. ${ }^{145}$ Both parties will now have a very good idea of their relative levels of interest and the potential fit of the candidate with the particular school. At the end of the initial interviews, the school will conduct background checks in order to make its final decisions about whom to invite back. ${ }^{146}$

On-campus interviews are scheduled for three or four candidates, any one of whom the university would be happy to hire as its new coach. These interviews are designed to sell the school to the coach. The potential hire will meet with the college president, key trustees, and important administrators. At the end of these meetings, the university will have established its internal ranking of the candidates. ${ }^{147}$ The university will negotiate with each of the potential candidates until they are confident that they can land their highest choice among those seriously interested in the job. ${ }^{148}$ The most difficult point of preliminary negotiations is the amount of the buyout clause in the coach's contract. ${ }^{149}$ Compensation issues normally are resolved by benchmarking the contract against other coaches' contracts at similar universities or within the school's conference. ${ }^{150}$ In order to avoid having

\footnotetext{
141. Mark Schlabach, How Jimmy Sexton Became College Football's Ultimate Power Broker, ESPN (Dec. 1, 2015), http://espn.go.com/collegefootball/story/_id/14239090/jimmy-sexton-college-football-power-broker-scenes.

142. See Thomas \& Van Horn, supra note 50, at 206 (mentioning that there is an informal agreement amongst athletic directors to "not solicit one another's coaches without prior permission"); see also O'Neil, supra note 138 (stating that one of the search firm's duties is to contact coaches and their respective agents).

143. Thomas \& Van Horn, supra note 50, at 207.

144. Id.

145. Tom Dienhart, The Dynamics of a Coaching Search, RIVALS.COM (Dec. 20, 2009), https://perma.cc/PX49-WHHJ ("If everything lines up correctly, a candidate is interviewed by the school. Often, the interview will take place in an out-of-the-way location to keep the process as far from the public eye as possible.").

146. Thomas \& Van Horn, supra note 50, at 208.

147. Id. at 208-09.

148. Id. at 209 (" $[\mathrm{T}]$ he school will continue to negotiate in secret with several candidates simultaneously until they are confident that their preferred candidate will accept the job.").

149. Id. at 209.

150. See generally id. at 207.
} 
to publicly admit that it did not get its first choice, the university will not make a job offer to any candidate without being sure that the candidate will accept. ${ }^{151}$

After the coach accepts the position, his agent will negotiate some of the remaining terms of the employment contract with the agent's counterpart at the university or outside counsel for the university. Terms to finalize might include the definition of "cause" in the termination provisions of the contract, or the form(s) of incentive pay that the coach will be eligible to receive under certain circumstances. Both sides have strong incentives to successfully conclude these negotiations. ${ }^{152}$

\section{G. Comparing College President and Football Coach Hiring Processes}

Comparing the process of recruiting and selecting college presidents with finding replacement football coaches, there are many similarities but also some clear differences. Three key differences are that: (1) football coaches routinely use agents to negotiate their contractual terms of employment, whereas college presidents do not; (2) executive search firms are almost always used in football coach searches, while in college president searches they are used less frequently (although they are becoming more common); and (3) football coaches generally have buyout clauses in their contracts that require them to pay the university if they leave voluntarily but provide hefty severance payment provisions if the university terminates them without cause, whereas college presidents normally do not have such clauses in their employment contracts. ${ }^{153}$

The principal effect of these differences is that the football coach recruiting process is more highly professionalized than the one currently in place for college presidents. ${ }^{154}$ Agents forcefully represent their clients' interests to ensure that their compensation levels and contractual protections are benchmarked against the terms of similarly placed coaches at other schools throughout the country. ${ }^{155}$ Experienced search firms specialize in football coach searches, speeding up the dissemination of information and helping to move coaches from one school to another. ${ }^{156}$ More frequent turnover in the coaches' ranks leads schools to insist on compensation in the event a coach leaves to take a better job. Coaches seek compensation in the highly likely event that they are terminated without cause at some stage of their career. ${ }^{157}$ With this as background, we turn next to a close comparison of these executives' contracts.

\section{College President vs. Football Coach Contracts}

College presidents, by definition, are the highest-ranking employees at their institutions. A football coach, by comparison, reports to the university's AD, who in turn reports to the college president. In most organizations, the president is the highest-paid employee, and we might therefore expect that the college president

151. Id. at 209.

152. See id. at 230

153. Id. at $235-37$.

154. Id. at $205-09$.

155. Id. at 207.

156. See id. at 205-06.

157. Id. at $235-37$. 
would be paid more and have better contractual protections in their employment agreements than the football coach. Does this hold true at universities as well? To address this question, we begin by discussing our data collection process, then move on to compare the compensation levels and its forms for both types of university employees and finish by examining the legal terms in both sets of contracts.

\section{A. Data Collection and Comparison of the Samples}

In our prior work, we generated a list of all the FBS Division I public universities and obtained the employment contracts for their football coaches. ${ }^{158}$ In order to create a matching set of employment contracts for college presidents, we sent Freedom of Information Act ("FOIA") requests to each of these public universities using their state law FOIA statutes. Private universities do not have to make these disclosures under the state FOIA statutes so we were not able to obtain those agreements.

We obtained most of the college president employment contracts from 1995 to 2013 from the schools that responded to our requests. In some cases involving older contracts, schools had documentation retention policies that resulted in the disposal of the relevant contracts, but we have virtually complete data for the period of 2005 to $2013 .{ }^{159}$ As with our prior project, there were a few public schools located in jurisdictions where state law does not require disclosure of these documents, ${ }^{160}$ and we were unable to obtain those contracts. A handful of other public universities did not respond. ${ }^{161}$

Although historically college presidents did not sign written agreements, such formal employment contracts are on the rise, ${ }^{162}$ we collected 596 such contracts in our sample. Table $1 \mathrm{~A}$, below, provides an overview of the college president contracts that are in our sample. We define employment contracts as the initial agreement between the college and the employee that is assuming the role of top executive at the school. ${ }^{163}$ The college president's "first employment contract is especially important, because it sets the base for future adjustments and defines the expectations and process for review." 164 The second group of contracts constitutes amendments to employment contracts. These are agreements that are entered into after the initial employment agreement, usually after a significant period of time. Generally, these amendments are adopted to change the compensation amounts paid

158. See generally id.

159. There are a few contracts which schools have not provided, such as Gordon Gee's initial contract with Ohio State University.

160. Thomas \& Van Horn, supra note 50, at 213 n.41.

161. Id. Some schools, such as Auburn and Clemson, had no records of contracts with their respective presidents.

162. NEFF \& LEONDAR, supra note 58 , at 82 (" $[\mathrm{T}]$ he use of contracts is on the upswing in four-year institutions.").

163. This means that we excluded agreements for positions below the president where the employee was previously working for the college prior to being appointed as president. In a few cases, the college expressly adopted a pre-existing contract as the new president's contract, and in this event, we coded these contracts as employment contracts.

164. ATWELl \& WeLlman, supra note 12, at 36. 
to the president, but they can also alter other terms of the contract. ${ }^{165}$ Over the course of their tenure, presidents may execute more than one amendment to their initial employment agreement. There are 221 of these contracts in our sample.

A third form of agreement is an amended and restated employment contract. Employers typically enter into these agreements with their top employees after there have been several contract amendments or when they desire to make more significant changes to their president's terms of employment. ${ }^{166}$ At the time they execute the amended or restated contracts, the parties have usually already made several changes to the initial contract, and the parties want to incorporate all of the previous changes, as well as additional changes, into a new contract that embodies their complete understanding with the university. ${ }^{167}$ We collected 134 of these contracts in our sample.

Finally, we have a set of 44 interim president employment contracts. Interim presidents are normally hired for a limited time to run the college in a caretaker role while the college is searching for a new president. These contracts are quite different from college president contracts because there is generally no expectation that the interim president will be hired for an ongoing position as president. ${ }^{168}$ Instead, the interim presidents' job is just to manage the school's business affairs for the time necessary for the search process to be completed and a new president to step in on a full-time basis. ${ }^{169}$ We do not include these contracts in the remaining part of our analysis because they are not directly comparable to the other types of presidents' contracts. ${ }^{170}$ There are no interim football coach contracts in our sample.

165. See, e.g., Second Amendment to Emp't Contract between the Bd. of Regents of the Univ. of Wash. and Mark Emmert, President Univ. of Wash. (Nov. 6, 2006) (on file with author) (adding additional deferred compensation plan); Second Amendment to Emp't Agreement between Teresa A. Sullivan, President Univ. of Va., and the Rector and Visitors of the Univ.of Va. (June 18, 2012) (on file with author) (adding a mediation clause).

166. See Randall Thomas et al., Arbitration Clauses in CEO Employment Contracts: An Empirical and Theoretical Analysis, 63 VAND. L.R. 959, 978 (2010).

167. $I d$.

168. See Charles B. Neff, The Transitional Presidency, 31 AGB REP. 16, 16-21 (Sept. 1989) ( stating that an interim president serves a specified period of time and is not a candidate for the presidency).

169. See NEFF \& LEONDAR, supra note 58, at 12-13 (stating that an interim president has limited duties for a specified period of time).

170. Compare Emp't Contract between the Bd. of Trustees of State Insts. of Higher Learning of the State of Miss. and Vance Watson, Interim President of Miss. State Univ. (Apr. 1, 2008) (on file with author) (discussing few clauses other than base salary and rights of termination) with Emp't Contract between the Bd. of Trustees of State Insts. of Higher Learning of the State of Miss. and Dr. Mark Keenum, President Miss. State Univ. (Jan. 5, 2009) (on file with author) (stating that Mark Keenum would receive a base salary as well as supplemental salary from boosters and that six additional clauses are attached to the contract). 


\begin{tabular}{|c|c|c|}
\hline $\begin{array}{c}\text { President Contracts } \\
\text { by Contract Type }\end{array}$ & Number & $\begin{array}{c}\text { Percentage of } \\
\text { Sample }\end{array}$ \\
\hline Employment Contract & 197 & $32.8 \%$ \\
\hline $\begin{array}{c}\text { Amendment to } \\
\text { Employment Contract }\end{array}$ & 221 & $36.8 \%$ \\
\hline $\begin{array}{c}\text { Amended and Restated } \\
\text { Employment Contract }\end{array}$ & 134 & $22.3 \%$ \\
\hline $\begin{array}{c}\text { Employment Agreement for } \\
\text { Interim President }\end{array}$ & 44 & $7.3 \%$ \\
\hline No Agreement & 4 & $0.7 \%$ \\
\hline Total & $\mathbf{6 0 0}$ & $\mathbf{1 0 0 \%}$ \\
\hline
\end{tabular}

Table 1A: Description of College President Contracts Sample (1995-2014)

Finally, we note that there are a small number of college presidents that did not have written employment contracts. As we discuss below, the football coaches in our sample all have written employment contracts as well, although public corporation CEOs frequently do not have such contracts. ${ }^{171}$ One possible reason why college presidents are unlike CEOs in this regard is that college presidents may have relatively smaller amounts of firm-specific investments in their schools than CEOs have in the firms they work for. This makes it relatively less expensive for a school to replace the skills of the college president. For that reason, a college president is in a position with more general skills and should seek to execute an employment agreement. ${ }^{172}$

In Table 1B, we describe our sample of football coaches. The sample period-2005 to 2013 - differs slightly from that used in Table 1A (1995-2014) because of data availability issues. The first three categories shown-employment contract, amendment to employment contract, and amended and restated employment contract-have the same definitions as in Table 1A. When we compare the values in the two tables for the first three categories, we see important differences. First, there are more football coach contracts than college president contracts over a far shorter time period. There are also more amendments to employment contracts, but far fewer amended and restated contracts.

These differences reflect the relatively short tenure of football coaches compared to college presidents. When we calculate the average job tenure for college presidents we find it is 7.6 years, with a median tenure of 6.0 years. By comparison, the average tenure for football coaches is 4.6 years, and the median is

171. Stuart L. Gillan et al., Explicit Versus Implicit Contracts: Evidence from CEO Employment Agreements, 64 J. FIN. 1629, 1629 (2009).

172. Cf. id. at 1634. 
only 3.0 years. Given the relatively rapid turnover of football coaches compared to college presidents, we expected that coaches would enter a larger number of initial contracts. Based on our prior work, we also expected a larger number of football coach contract amendments since they are frequently awarded for good performance to ward off competing job offers. Similarly, we expected fewer amended and restated employment contracts for football coaches because they frequently do not remain employed by the same school as long as college presidents and are, therefore, less likely to need to enter into an amended and restated contract.

\begin{tabular}{|c|c|c|}
\hline $\begin{array}{c}\text { Coach Contracts } \\
\text { by Contract Type }\end{array}$ & Number & $\begin{array}{c}\text { Percent of } \\
\text { Sample }\end{array}$ \\
\hline Employment Contract & 495 & $52.0 \%$ \\
\hline $\begin{array}{c}\text { Amendment to } \\
\text { Employment Contract }\end{array}$ & 397 & $42.0 \%$ \\
\hline $\begin{array}{c}\text { Amended and Restated } \\
\text { Employment Contract }\end{array}$ & 42 & $4.5 \%$ \\
\hline $\begin{array}{c}\text { Other Agreement Including } \\
\text { Employment Terms }\end{array}$ & 13 & $1.5 \%$ \\
\hline Total & $\mathbf{9 4 7}$ & $\mathbf{1 0 0 \%}$ \\
\hline
\end{tabular}

Table 1B: Description of Football Coaches Contracts Sample (2005-2013)

The final category of football coach contracts is other agreements including employment terms. This small category of contracts is comprised of memorandums of understanding, offer letters, or letters of appointment. Memorandums of understanding and offer letters are essentially temporary employment contracts that supply the terms of employment while full written contracts are negotiated. ${ }^{173}$ Letters of appointment are an abbreviated type of employment contract and are rarely used.

We attribute the difference in job tenure to the relative ease of measuring success for coaches: a football coach is evaluated by his win-loss record, and a consistently losing coach will generally cost his college substantial revenues and be fired. By contrast, given the diffuse relationship between a president's actions and a university's overall performance, it will take longer to identify poorly performing college presidents and discharge them.

The relatively frequent need to replace coaches has other implications as well. One result of these frequent changes is that the coach recruitment process has become highly professionalized. ${ }^{174}$ Coaches routinely employ agents to represent them in all employment matters, and schools respond by using executive search

173. Thomas \& Van Horn, supra note 50, at 207.

174. Id. at 205-09. 
firms in almost all searches as well. Coaches' contracts are subject to extensive negotiations and, as we see from the large number of contract amendments shown in Table 1B, frequent changes. While the recruitment process for college presidents is moving in this direction, it still remains less frequently run by professional search firms and agents than that for football coaches. In the next section, we turn to a comparison of college president and football coach compensation.

\section{B. Comparing College President and Football Coach Compensation}

We begin our analysis by looking at the overall compensation levels and the breakdown of pay into its components. While some of this information is contained in the employment contracts themselves, we also drew from other databases to obtain additional information. We begin with some temporal comparisons between the pay levels of college presidents and football coaches.

\section{Year-By-Year Comparisons}

In our sample, college president contracts contain information about their initial base compensation but lack data on several other forms of pay that are potentially important components of college president pay, including pay-forperformance amounts. In order to obtain complete information on college president compensation, we obtained access to the Chronicle of Higher Education's executive compensation database for public and private universities. This database has complete information on all forms of college president pay beginning in $2010 .{ }^{175}$ Table 2A, below, contains the average amounts of each different category of compensation for the college presidents in our sample for 2010-2014.

The definitions for the various components of pay are taken directly from the data dictionary supplied by the Chronicle of Higher Education. ${ }^{176}$ The values shown in the table are averages derived from the contracts of the college presidents in our sample during the specified year.

Several observations are immediately apparent. First, salary ("Base Compensation") is a very large percentage of total college president compensation, ranging from approximately $90 \%$ to $96 \%$ of total pay. This dwarfs all other forms of compensation, especially bonus pay, which leads us to conclude that college

175. Dan Bauman \& Brian O'Leary, Executive Compensation at Private and Public

Colleges, Chron. Higher Educ. (July 17, 2016),
http://www.chronicle.com/interactives/executive-compensation?cid\#id=table_public_2015.

176. They are as follows: "Base pay: total base salary provided to the chief executive, [in the fiscal year specified], including compensation from private universityrelated foundations." Bonus pay is the total "value of all bonuses and incentive compensation paid out to the chief executive" in the fiscal year. Severance pay is the total amount of "payments made to the chief executive upon his or her resignation or firing, as determined by his or her contract, separation agreement, or a legal settlement. This can include severance pay, unused vacation pay, or other agreed-upon separation pay." Deferred compensation paid out is the amount of deferred pay that was set aside in previous years and paid out in the year in question. Deferred compensation set aside in prior years is not included in total compensation. Retirement pay, or payments made by the university on behalf of the chief executive to a retirement plan during the fiscal year, is also not included in total compensation. $I d$. 
president pay is not very sensitive to performance. Second, from 2010 to 2014 college president total compensation did not rise rapidly: total pay only increased by $10 \%$ during this five-year time period, or less than $\$ 47,000$ overall.

Third, "[ten] years ago, performance bonuses were rarely a part of presidential compensation, but now they are increasingly common." ${ }^{177}$ However, the college presidents' contracts in our sample only occasionally disclose the criteria for the payment of bonuses. Even in those instances, the language used is very general and does not specify how the college's board of trustees will use the identified factors to determine bonus pay. For example, Neal Smatresk's contract with the University of North Texas stated that "the Board of Regents may approve on the recommendation of the Chancellor an annual bonus [of up to $25 \%$ of Smatresk's annual compensation] ... based on objectives determined and agreed to by the Chancellor and Smatresk." 178 It is unclear from the contract what weights the board of trustees attaches to each of these criteria and when a bonus will be paid. In other cases, performance goals are specified, but the method by which the board of trustees calculates the amount of performance pay is vague. For instance, James Cofer's contract with the University of Louisiana at Monroe required an annual evaluation based on three system-wide goals and stated: "Upon conclusion of the annual evaluation, the Board ... shall determine any adjustments to the annual salary, and/or benefits of the President." ${ }^{179}$ In any event, Table 2 A shows that pay for performance is a small fraction of total compensation for college presidents.

177. JOHNSTON \& FERRARE, supra note 59, at 136-37.

178. President's Emp't Agreement By and Between Univ. of N. Tex. Sys. and Neal Smatresk, President, Univ. of N. Tex. $\$ 4.03$ (Feb. 3, 2014) (on file with author).

179. Amendment to Letter of Appointment Between Board of Supervisors of the Univ. of La. Sys. and James Cofer, President, Univ. of La. (July 1, 2008) (on file with author). 


\begin{tabular}{|c|c|c|c|c|c|}
\hline & $\mathbf{2 0 1 0}$ & $\mathbf{2 0 1 1}$ & $\mathbf{2 0 1 2}$ & $\mathbf{2 0 1 3}$ & $\mathbf{2 0 1 4}$ \\
\hline $\begin{array}{c}\text { Number of } \\
\text { Presidents }\end{array}$ & 91 & 94 & 98 & 100 & 96 \\
\hline $\begin{array}{c}\text { Base } \\
\text { Compensation }\end{array}$ & $\$ 389,390$ & $\$ 401,372$ & $\$ 404,375$ & $\$ 402,011$ & $\$ 415,111$ \\
\hline $\begin{array}{c}\text { Bonus } \\
\text { Compensation }\end{array}$ & $\$ 15,589$ & $\$ 19,375$ & $\$ 17,071$ & $\$ 25,676$ & $\$ 26,275$ \\
\hline $\begin{array}{c}\text { Severance } \\
\text { Compensation }\end{array}$ & $\$ 0$ & $\$ 584$ & $\$ 2,480$ & $\$ 25,650$ & $\$ 14,779$ \\
\hline $\begin{array}{c}\text { Deferred Paid Out } \\
\text { Compensation }\end{array}$ & $\$ 11,363$ & $\$ 16,702$ & $\$ 31,048$ & $\$ 50,148$ & $\$ 6,853$ \\
\hline $\begin{array}{c}\text { Deferred Set } \\
\text { Aside } \\
\text { Compensation }\end{array}$ & $\$ 43,999$ & $\$ 43,239$ & $\$ 44,742$ & $\$ 51,944$ & $\$ 41,693$ \\
\hline $\begin{array}{c}\text { Retirement } \\
\text { Compensation }\end{array}$ & $\$ 31,348$ & $\$ 30,662$ & $\$ 38,054$ & $\$ 34,420$ & $\$ 39,088$ \\
\hline $\begin{array}{c}\text { Total } \\
\text { Compensation }\end{array}$ & $\mathbf{\$ 4 1 6 , 3 4 3}$ & $\mathbf{\$ 4 3 7 , 9 9 1}$ & $\mathbf{\$ 4 5 4 , 9 7 3}$ & $\mathbf{\$ 5 0 3 , 4 8 5}$ & $\mathbf{\$ 4 6 3 , 0 1 8}$ \\
\hline $\begin{array}{c}\text { Base } \\
\text { Percentage }\end{array}$ & $\mathbf{9 5 . 8 \%}$ & $\mathbf{9 3 . 9 \%}$ & $\mathbf{9 3 . 5 \%}$ & $\mathbf{8 9 . 8 \%}$ & $\mathbf{9 2 . 0 \%}$ \\
\hline
\end{tabular}

Table 2A: College Presidents' Total Average Compensation (By Year)

Total deferred pay is the second-most important component of college president compensation. For example, in 2014, total deferred pay is the sum of deferred paid out compensation $(\$ 41,693)$ plus deferred set aside compensation $(\$ 39,088)$, or about $17 \%(\$ 80,781)$ of total compensation. Section 457 of the Internal Revenue Code allows college presidents to have deferred compensation set aside without being included in the president's current taxable income if the benefit is subject to "a substantial risk of forfeiture." 180 This generally requires that there "must be a substantial future service requirement that the chief executive will not necessarily meet as a condition of receiving the benefits-a minimum term of service in the presidency, certain performance goals, or both." ${ }^{181}$ Other more complex tax strategies may also be used to allow the president to defer taxes on this type of compensation. ${ }^{182}$

Table 2B, below, displays the fixed pay components for FBS Division I football coach compensation for the years 2005, 2009, and 2013. We selected these three years in an effort to show the trend over time of football coach fixed pay, and because we could pull complete data from the contracts we previously collected.

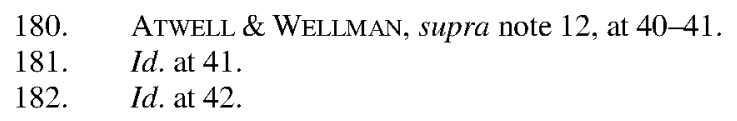


Using our football coach contract data, we pulled out the various compensation components. The first component, salary, is defined as the amount of base salary listed in the coach's employment contract. In situations where salary changes over time, we continued to use the amount shown in the contract until a new contract, or an amendment to the existing contract, was entered into, at which point we revised the salary figure to reflect the amount in the new agreement. This was a reasonable course of action given the overall frequency of contract revisions for football coaches.

A football coach's largest fixed-pay component is service compensation. Service compensation is the amount of fixed pay that the coach receives from any radio, television, internet, speeches, alumni club appearances, or other similar arrangements. ${ }^{183}$ As with salary, we used the amounts reported in the coach's employment contract. We updated this amount whenever the coach entered into a new employment contract or executed an amendment to an existing contract. In a few cases, we could not unpack salary from service compensation because they are listed together; in those instances, we entered the total amount as salary so that service income will be underreported. Overall compensation levels, however, are unaffected by this allocation.

The third component of football coach pay is "Camp." This is fixed pay that a coach receives when he participates in a summer football camp. These payments may be made by the university if the camp is university run, or alternatively, the coach may run the camp himself, collect the monies from participants, and pay all of the related expenses.

Endorsement pay is the final component of football coach fixed pay. Universities often pay coaches pursuant to apparel, shoe, equipment, and other endorsement contracts that the university enters into with outside businesses. We entered the initial dollar amount stated in the employment contract similar to the other components of fixed pay.

183. Thomas \& Van Horn, supra note 50, at 217. 


\begin{tabular}{|c|c|c|c|}
\hline $\begin{array}{c}\text { Form of } \\
\text { Compensation }\end{array}$ & $\begin{array}{c}\text { Contract Year } \\
\mathbf{2 0 0 5}\end{array}$ & $\begin{array}{c}\text { Contract Year } \\
\mathbf{2 0 0 9}\end{array}$ & $\begin{array}{c}\text { Contract Year } \\
\mathbf{2 0 1 3}\end{array}$ \\
\hline Salary & $\$ 252,974$ & $\$ 405,631$ & $\$ 547,167$ \\
\hline Service & $\$ 396,486$ & $\$ 646,741$ & $\$ 900,277$ \\
\hline Camp & $\$ 1,964$ & $\$ 9,865$ & $\$ 4,311$ \\
\hline Endorsement & $\$ 73,750$ & $\$ 76,047$ & $\$ 119,067$ \\
\hline $\begin{array}{c}\text { Total Fixed } \\
\text { Compensation }\end{array}$ & $\$ 725,174$ & $\$ 1,138,285$ & $\$ 1,570,823$ \\
\hline Percentage Salary & $34.88 \%$ & $35.63 \%$ & $34.83 \%$ \\
\hline Percentage Service & $54.67 \%$ & $56.81 \%$ & $57.31 \%$ \\
\hline
\end{tabular}

Table 2B: Football Coach Average Fixed Compensation

Examining Table 2B, we see that from 2005 to 2013 , football coach fixed compensation increased by $\$ 845,649$, or more than $100 \%$ of its 2005 level. This is more than ten times the rate of increase for total college president pay over the 20102014 time period shown in Table 2A. Service compensation is the most important element of football coach pay, rising from around $\$ 400,000$ in 2005 to more than $\$ 900,000$ in 2013. Moreover, its importance has increased as a percentage of total football coach compensation over that same period.

The large increase for coaches is likely due to television and bowl revenue attributable to college football. ${ }^{184}$ The SEC's experience is informative. In the 20142015 fiscal year, the SEC generated $\$ 112$ million from bowl games and an additional $\$ 347$ million in TV deals. On a per-school basis, that meant roughly $\$ 25$ million from television and an additional $\$ 8$ million from bowl games. ${ }^{185}$ By comparison, for 2017-2018, the SEC projects that after renegotiating its ESPN television contract each member school will receive in excess of $\$ 44$ million annually. ${ }^{186}$ Similar deals at the other Power Five Conferences are projected to result in revenues in excess of $\$ 20$ million in $2014-2015,{ }^{187}$ with likely more to come in the future. ${ }^{188}$ College presidents are unlikely to be able to show this type of value return.

In our earlier paper on football coaches, we calculated the potential level for bonus payments for football coaches under a variety of different provisions in

184. Id. at 218 .

185. Alsher, supra note 7.

186. Smith, supra note 9.

187. Id.

188. See, e.g., Clay Travis, Every SEC School Will Make More TV Money Than Texas, Notre Dame, OutKick Coverage: College Football Blog (July 23, 2014, 10:57 AM), http://www.outkickthecoverage.com/every-sec-school-will-make-more-tv-moneythan-texas-notre-dame-072314 (stating that the SEC, Notre Dame, and Texas have their own television deals). 
their agreements. ${ }^{189}$ Specifically, we analyzed potential bonus payments for on-field performance (such as winning the team's conference championship) and bonuses for team academic performance levels (as measured by GPA, for instance) ${ }^{190}$ Excellent on-field performance can substantially increase football coach compensation, but academic performance bonuses (bonuses based on the team's academic successes) were a relatively small percentage of on-field bonuses. ${ }^{191}$ Given the relatively trivial amounts of college presidents' performance bonus payments, it is apparent that football coach pay-for-performance is much more substantial in amount.

\section{Compensation Comparisons by Size}

To examine the effects of school size on college presidents' total compensation, Table $3 \mathrm{~A}$ presents 2013 data on the distribution of their total pay by quartiles from the smallest undergraduate schools to the largest. All of the compensation components are as defined in Table $2 \mathrm{~A}$. As we expected, there is a substantial difference between total compensation for college presidents at the smallest schools and those at the largest schools. ${ }^{192}$ The difference is most pronounced for the base compensation levels, with the data showing a distinct upward trend as the undergraduate population increases. This size difference may be driven by a number of factors. For example, as with television contracts and football coaches, the size differential for college president compensation may be the result of the much greater revenues that are generated by having a larger undergraduate population. ${ }^{193}$ Another possible explanation may be that the larger institutions are more complex and more difficult to run, which creates the need to recruit more talented leaders that require higher pay.

189. Thomas \& Van Horn, supra note 50, at 219-21.

190. Id.

191. Id.

192. This finding is consistent with prior research. See Jeffrey Pfeffer \& Jerry Ross, The Compensation of College and University Presidents, 29 RES. HIGHER EDUC. 79, 85 (1988).

193. See id. at 89 (finding presidents in larger, richer, private universities earn more, but the effect of size is greater in private universities than in public). 


\begin{tabular}{|c|c|c|c|c|}
\hline $\begin{array}{c}\text { Form of } \\
\text { Compensation }\end{array}$ & $\begin{array}{c}\text { Smallest } \\
\text { Quartile }\end{array}$ & $\begin{array}{c}\text { Second } \\
\text { Quartile }\end{array}$ & $\begin{array}{c}\text { Third } \\
\text { Quartile }\end{array}$ & $\begin{array}{c}\text { Largest } \\
\text { Quartile }\end{array}$ \\
\hline $\begin{array}{c}\text { Base } \\
\text { Compensation }\end{array}$ & $\$ 351,198$ & $\$ 415,941$ & $\$ 443,993$ & $\$ 472,555$ \\
\hline $\begin{array}{c}\text { Bonus } \\
\text { Compensation }\end{array}$ & $\$ 16,168$ & $\$ 18,986$ & $\$ 18,994$ & $\$ 54,625$ \\
\hline $\begin{array}{c}\text { Severance } \\
\text { Compensation }\end{array}$ & $\$ 15,833$ & $\$ 0$ & $\$ 0$ & $\$ 42,898$ \\
\hline $\begin{array}{c}\text { Deferred Paid-Out } \\
\text { Compensation }\end{array}$ & $\$ 3,373$ & $\$ 9,557$ & $\$ 9,091$ & $\$ 6,656$ \\
\hline $\begin{array}{c}\text { Deferred } \\
\text { Set-Aside } \\
\text { Compensation }\end{array}$ & $\$ 42,376$ & $\$ 46,441$ & $\$ 46,053$ & $\$ 31,652$ \\
\hline $\begin{array}{c}\text { Retirement } \\
\text { Compensation }\end{array}$ & $\$ 42,708$ & $\$ 34,158$ & $\$ 41,707$ & $\$ 36,462$ \\
\hline $\begin{array}{c}\text { Total } \\
\text { Compensation }\end{array}$ & $\mathbf{\$ 3 8 6 , 5 7 3}$ & $\mathbf{\$ 4 4 4 , 4 8 4}$ & $\mathbf{\$ 4 7 2 , 0 7 8}$ & $\mathbf{\$ 5 7 6 , 7 3 4}$ \\
\hline $\begin{array}{c}\text { Base Percentage of } \\
\text { Total Compensation }\end{array}$ & $\mathbf{9 2 \%}$ & $\mathbf{9 5 \%}$ & $\mathbf{9 6 \%}$ & $\mathbf{8 5 \%}$ \\
\hline
\end{tabular}

Table 3A: College Presidents' Total Compensation (2013) (by Quartile)

There are several interesting aspects to this table. First, bonus compensation, while generally small, is almost three times higher the universities in the largest quartile than at all other schools. One potential explanation for this difference is that larger organizations have better observable performance metrics. For example, larger universities have more alumni and therefore more potential alumni donations. With more alumni, and greater potential to raise money, a college president's efforts in fundraising might be more easily measured, and therefore, his or her success can be more directly rewarded. ${ }^{194}$

Second, severance pay at the largest schools is almost three times higher than any other category of universities, and is zero at two of the others. These payments are normally contingent on the college president being terminated without cause by the school. ${ }^{195}$

Third, some compensation levels are higher at the smaller quartile schools than the largest schools. Deferred compensation is higher at all of the three smaller quartile schools. Retirement compensation is higher at two of the three smaller quartile schools than they are at the largest schools. These differences are relatively

194. See generally Jensen \& Meckling, supra note 27, at 323-24 (firms should compensate employees based on the value that they create for the company).

195. For further discussion of termination without cause for college presidents, see infra Section III.D.3. 
small compared to base compensation differences, but they may reflect an effort to offset the large disparity in overall pay for college presidents of larger schools.

For comparison, Table 3B shows football coach fixed compensation by the size of the schools' football programs. To make it more comparable to the college president data in Table 3A, we show 2013 data. The most striking aspect of these data is that schools in the largest quartile of football programs pay their coaches fixed compensation that is six times more than schools in the smallest quartile. Service income is the main driver of these differences, most likely because of the large differences in television revenues for the bigger universities.

\begin{tabular}{|c|c|c|c|c|}
\hline $\begin{array}{c}\text { Form of } \\
\text { Compensation }\end{array}$ & $\begin{array}{c}\text { Smallest } \\
\text { Quartile }\end{array}$ & $\begin{array}{c}\text { Second } \\
\text { Quartile }\end{array}$ & $\begin{array}{c}\text { Third } \\
\text { Quartile }\end{array}$ & $\begin{array}{c}\text { Largest } \\
\text { Quartile }\end{array}$ \\
\hline Salary & $\$ 281,303$ & $\$ 517,722$ & $\$ 481,714$ & $\$ 903,409$ \\
\hline Service & $\$ 125,321$ & $\$ 481,704$ & $\$ 1,015,983$ & $\$ 1,498,872$ \\
\hline Endorsement & $\$ 6,206$ & $\$ 61,252$ & $\$ 48,500$ & $\$ 252,704$ \\
\hline $\begin{array}{c}\text { Total Fixed } \\
\text { Compensation }\end{array}$ & $\mathbf{\$ 4 1 2 , 8 3 2}$ & $\mathbf{\$ 1 , 0 7 4 , 6 7 9}$ & $\mathbf{\$ 1 , 5 5 2 , 4 4 7}$ & $\mathbf{\$ 2 , 6 6 4 , 9 5 5}$ \\
\hline
\end{tabular}

Table 3B: Football Coach Fixed Compensation (2013) (by Quartile)

Football television contracts disproportionately benefit the bigger schools with the better-known football programs. ${ }^{196}$ The size of the university is also a driver of college president compensation. ${ }^{197}$ For example, presidents at larger universities can create greater value for the university through fundraising from a larger alumni base. ${ }^{198}$ Greater school size also is associated with greater job complexity and a greater number of job duties. Larger schools will need more highly qualified personnel, who command a higher labor market premium, to effectively run them. ${ }^{199}$ For coaches, the size effect on compensation arises because most large college football programs are members of one of the Power Five Conferences where revenue from TV and bowl appearances is significantly higher than at other schools. Greater value creation by coaches at the larger schools leads to greater compensation.

Having examined the large differences in compensation based on school and program size, we turn next to a comparison of compensation differences between college presidents and football coaches at the same schools.

196. Kristi Dosh, A Comparison: Conference Television Deals, ESPN (Mar. 19, 2013), http://www.espn.com/blog/playbook/dollars/post/_id/3163/a-comparisonconference-television-deals (stating that the former Big East Conference, a conference known largely for its basketball teams, will make $\$ 126$ million over seven years, while the PAC-12 which is a strong football conference makes $\$ 250$ million annually).

197. Pfeffer \& Ross, supra note 191, at 87-89 (finding that the size of a university affected presidential compensation).

198. See ATwell \& Wellman, supra note 12, at 12-13.

199. See Banker et al., supra note 13, at 24. 


\section{Differences Between College Presidents and Coaches by School}

Another way of drawing comparisons between football coach compensation and college president compensation is to do a school-by-school comparison of the differences between them. In order to make the comparison meaningful, we selected a single sample year-2012- to do the calculation. Table 4 presents these results with the schools grouped into two categories: the Power Five Conferences and all other FBS Division I schools. For each group, we compared the differences between football coaches' and college presidents' salaries and total compensation.

\begin{tabular}{|c|c|c|c|c|c|c|}
\hline \multicolumn{7}{|c|}{ Power Conferences } \\
\hline \multicolumn{4}{|c|}{ Salary } & \multicolumn{3}{|c|}{ Total Compensation } \\
\hline & President & Coach & Ratio & President & Coach & Ratio \\
\hline Mean & $\$ 429,851$ & $\$ 751,029$ & 2.19 & $\$ 453,336$ & $\$ 2,651,112$ & 6.59 \\
\hline Median & $\$ 425,000$ & $\$ 400,000$ & 0.98 & $\$ 425,020$ & $\$ 2,349,995$ & 5.55 \\
\hline \multicolumn{7}{|c|}{ All Other FBS Division I Schools } \\
\hline \multicolumn{4}{|c|}{ Salary } & \multicolumn{3}{|c|}{ Total Compensation } \\
\hline & President & Coach & Ratio & President & Coach & Ratio \\
\hline Mean & $\$ 401,865$ & $\$ 360,895$ & 0.89 & $\$ 438,761$ & $\$ 712,576$ & 1.61 \\
\hline Median & $\$ 386,000$ & $\$ 300,000$ & 0.71 & $\$ 397,500$ & $\$ 510,634$ & 1.29 \\
\hline
\end{tabular}

Table 4: Compensation Differences: Football Coaches and College Presidents by School (2012)

The results are quite revealing. First, on average, Power Five coaches are paid twice as much as the presidents of their home schools, although the median data is almost identical (with presidents actually slightly higher). At all other FBS Division I schools, however, college presidents' salaries are somewhat higher for both the mean and median measures. Second, a cross-conference comparison of the salary data shows that both college presidents and football coaches are paid more at the Power Five Conference schools, although the differences in coaches' salaries are much more significant. Most striking is that average salaries for Power Five Conference football coaches are more than twice the average salaries paid to football coaches at all other FBS Division I schools. In fact, the average salaries paid to Power Five football coaches exceed the average total compensation of football coaches at all other FBS Division I schools.

There is one other stark difference in the total compensation numbers. In the Power Five Conferences, on average, football coaches make 6.59 times what college presidents make overall, and the median differences are almost as large. As can be seen from Table 2B, above, service income (largely television revenues) is the biggest driver of these huge differences. For all other FBS Division I schools, football coaches receive higher average and median pay than college presidents, but the differences are much smaller (e.g. 1.61 times the average pay). The cross- 
conference comparisons show large differences between total pay for Power Five Conference football coaches and the total pay of football coaches at all other FBS Division I schools, with the average Power Five Conference coach getting about 3.7 times more. The same comparison for college presidents shows that the pay differences between the two groups are quite small.

Overall, it is the football coaches at the Power Five Conferences whose pay is so much different from that of all of the college presidents and that of the football coaches at other conferences. As we discussed above, these differences appear to be driven by the wide disparity between the television and bowl revenues paid to the Power Five Conference schools, many of which have their own television networks and multiple bowl-tie-in contracts. ${ }^{200}$

\section{Perquisite Comparisons}

Another form of compensation is perquisites. The contracts we examined have data on the level of perquisites for each coach and each college president. Table $5 \mathrm{~A}$ contains information about college president perquisites and how they have evolved over time. We focus on three important types of perquisites: country club memberships, campus residences, and the use of a university car ${ }^{201}$ Beginning with country club memberships, we see that a sizeable majority of college presidents are provided with such a membership in their employment contracts. However, there is a clear downward trend in the percentage that is receiving this perquisite. Between 1995 and 2001, roughly $84 \%$ were given a membership, whereas between 2008 and 2014 , this percentage dropped to about $69 \%$, an overall decrease of $15 \%$. This could reflect a decline in the importance of country clubs in American society. ${ }^{202}$

The other two major perquisites that are provided for in employment contracts, campus residences and cars, have shown significant variations in their presence over time. A substantial percentage of college presidents, for example, are required by their employment contracts to live in a college-owned house on campus as part of their duties and to use it for entertaining alumni and others. ${ }^{203}$ For instance, as of the latest time period, 2008-2014, approximately $45 \%$ of all college presidents were required to reside in an on-campus, university-provided house. In the bare majority of contracts, there is no mention of this requirement, although housing may be covered in another agreement.

200. See, e.g., Clay Travis, Every SEC School Will Make More TV Money than Texas, Notre Dame, Outkick Coverage: College Football Blog (July 23, 2014, 10:57 AM), http://www.outkickthecoverage.com/every-sec-school-will-make-more-tv-moneythan-texas-notre-dame-072314 (stating that the SEC, Notre Dame, and Texas have their own television deals).

201. Other studies have found additional perquisites in some college president contracts, including entertainment allowances, life insurance, professional development, and provisions for health and wellness. JOHNSTON \& FERRARE, supra note 59, at 136.

202. See, e.g., Richard J. Moss, Golf and the American Country Club 145 (2001) (noting the "steady decline in the importance of the private country club as an institution").

203. NEFF \& LEONDAR, supra note 58, at 77 ("The majority of institutions, however, do provide a president's house or a housing allowance as part of the compensation package and because they expect the president to carry on a certain amount of entertaining at home."). 


\begin{tabular}{|c|c|c|c|}
\hline \multicolumn{4}{|c|}{ Club Menbership } \\
\hline & 1995-2001 & $2002-2007$ & $2008-2014$ \\
\hline $\begin{array}{l}\text { Club Membership } \\
\text { Provided }\end{array}$ & $84.15 \%$ & $79 \%$ & $68.87 \%$ \\
\hline No Mention & $15.85 \%$ & $21 \%$ & $31.13 \%$ \\
\hline \multicolumn{4}{|c|}{ Campus Residence } \\
\hline & 1995-2001 & $2002-2007$ & $2008-2014$ \\
\hline $\begin{array}{c}\text { On-Campus } \\
\text { Residence Required }\end{array}$ & $41.98 \%$ & $33 \%$ & $45.17 \%$ \\
\hline $\begin{array}{c}\text { On-Campus } \\
\text { Residence Permitted }\end{array}$ & $0 \%$ & $1.50 \%$ & $1.93 \%$ \\
\hline No Mention & $58.02 \%$ & $65.5 \%$ & $52.9 \%$ \\
\hline \multicolumn{4}{|c|}{ University Car } \\
\hline & 1995-2001 & $2002-2007$ & $2008-2014$ \\
\hline $\begin{array}{c}\text { Choice of } \\
\text { Car or Allowance }\end{array}$ & $1.22 \%$ & $3.16 \%$ & $5.28 \%$ \\
\hline Car is Provided & $32.93 \%$ & $24.74 \%$ & $34.15 \%$ \\
\hline No Mention & $65.85 \%$ & $71.58 \%$ & $60.57 \%$ \\
\hline
\end{tabular}

Table 5A: College President Perquisites (Percentage of Contracts)

Roughly $30-40 \%$ of college presidents are provided with a car or a car allowance as part of their employment terms. There is a small increase in this percentage over time. A majority of the college president employment contracts do not mention cars, but they could be provided in some other agreement. College presidents' free use of cars may be an important tool for facilitating performance of their duties, such as visiting alumni.

We expected to find that college presidents' employment contracts would also provide the executives with football tickets and personal skyboxes as part of their compensation packages. With the exception of one contract, ${ }^{204}$ however, such perquisites are not expressly mentioned. Given the tremendous importance of fundraising activities for FBS Division I college presidents at football games, we

204. Employment Agreement Between Bd. of Trustees of Mich. State Univ. and Lou Anna Kimsey Simon, President, Mich. State Univ. \$9 (Dec. 9, 2011) (stating "complimentary tickets to the University academic, athletic, and cultural events shall be made available for the President, her immediate family, and official guests"). 
speculate that all college presidents are provided with tickets and skyboxes (where they exist) as part of their jobs. It may be unnecessary to include them in the terms of their employment agreements.

For football coaches, the comparable set of perquisite data looks somewhat different. First of all, as Table 5B shows, there is a strong trend demonstrating increasing perquisites for football coaches over time. Cars, for instance, are now extremely common in their employment contracts $(87.1 \%$ for 2008-2013). Country club memberships have also steadily increased, appearing in a substantial majority of contracts $(62.8 \%)$. Football tickets $(60.4 \%)$ and skyboxes $(33.2 \%)$ are provided to coaches at many universities, perhaps in part to assist them in fundraising from alumni. One big difference in the availability of perquisites is the absence of campus residences for football coaches. This may be offset by a small, but increasing percentage of contracts with provisions for the coach's personal use of the university's plane.

\begin{tabular}{|c|c|c|c|}
\hline Perquisites & $\mathbf{1 9 9 5 - 2 0 0 1}$ & $\mathbf{2 0 0 2}-\mathbf{2 0 0 7}$ & $\mathbf{2 0 0 8 - 2 0 1 3}$ \\
\hline Car & $65.8 \%$ & $79.0 \%$ & $87.1 \%$ \\
\hline Skybox & $8.8 \%$ & $25.9 \%$ & $33.2 \%$ \\
\hline Tickets & $35.2 \%$ & $47.6 \%$ & $60.4 \%$ \\
\hline Club & $43.5 \%$ & $52.4 \%$ & $62.8 \%$ \\
\hline Airplane & $0.0 \%$ & $1.5 \%$ & $4.9 \%$ \\
\hline
\end{tabular}

Table 5B: College Football Coaches Perquisites

For both coaches and presidents, contractual perquisites align with the resources that will facilitate the performance of their jobs. University presidents need to spend a significant amount of time entertaining potential donors. Having a country club membership and a university house facilitates this, and their job performance improves. Football coaches spend much of their time recruiting new players every year, and therefore, are frequently on the road visiting recruits. Access to a car or a plane can reduce the wear and tear on the coach, making him more effective and successful at his job.

Having surveyed the compensation differences between college presidents and football coaches in Sections A and B above, we turn next to the legal terms of their employment contracts to see what additional insights can be gained from a comparison of these two important groups of employees. 


\section{Contract Length Comparisons}

Contract length is an important legal component that is contained in many employment contracts. ${ }^{205}$ Contract length is the result of a "compromise between the individual's need to have a period of commitment and the institution's need to review performance and possibly make adjustments within a reasonable time." ${ }^{206}$ Table 6 compares the contract length for college president employment contracts with those in football coaches' agreements.

While college presidents' contracts are becoming more likely to include a term of years, ${ }^{207}$ the most striking feature of Table 6 is that football coach employment contracts are more than twice as likely as college president contracts to have a fixed term. Furthermore, for those contracts that do contain a fixed term, football coach contracts are far more likely to be for a greater number of years. For example, roughly two-thirds of football coach contracts are for five years or more, whereas only slightly less than one-fifth of college president contracts are for such long terms. A third notable difference is that a sizeable fraction of college presidents work under contracts that state they are at-will employees of the university, whereas no college football coach contracts in this sample included that language.

\begin{tabular}{|c|c|c|}
\hline Contract Length in Years & College Presidents & Football Coaches \\
\hline At-Will Employment & $8.32 \%$ & $0.00 \%$ \\
\hline $\begin{array}{c}\text { Indefinite Term or } \\
\text { Term Not Provided }\end{array}$ & $45.47 \%$ & $0.75 \%$ \\
\hline 1 Year & $5.73 \%$ & $3.74 \%$ \\
\hline 2 Years & $2.59 \%$ & $2.46 \%$ \\
\hline 3 Years & $11.09 \%$ & $8.65 \%$ \\
\hline 4 Years & $7.21 \%$ & $18.38 \%$ \\
\hline 5 Years & $14.42 \%$ & $41.67 \%$ \\
\hline Greater Than 5 Years & $4.00 \%$ & $24.36 \%$ \\
\hline $\begin{array}{c}\text { Percentage of } \\
\text { Fixed-Term Contracts }\end{array}$ & $45.04 \%$ & $99.25 \%$ \\
\hline
\end{tabular}

Table 6: Contract Length Comparisons (Percentage of Contracts)

What accounts for these differences? One reason may be that college football coaches are more concerned about their job security than college presidents. As we noted earlier, football coaches' average tenure is 4.6 years and their median

205. "The contract should specify the term of the presidential appointment and include provisions for compensation if either the president or the board terminates employment before the end of the contract period." ATWELL \& WELLMAN, supra note 12, at 37.

206. JOHNSTON \& FERRARE, supra note 59, at 130.

207. NEFF \& LEONDAR, supra note 58, at 81 ("In recent years, there has been a distinct trend toward term appointments."). 
job tenure is only 3.0 years. Our data show that college presidents have a much longer average tenure ( 7.6 years) and median tenure ( 6.0 years). Given the relatively rapid turnover of football coaches compared to college presidents, football coaches will negotiate for greater contractual protections for their jobs, including fixed term lengths for more years, which can lead to higher severance payments if they are terminated early in the contract without cause. ${ }^{208}$

Another reason for longer football coach employment contracts relates to the recruitment process for college athletes. Football coaches must be able to assure potential high school recruits of their ability to coach the new recruits throughout their college careers. ${ }^{209}$ Given the intensive interactions football coaches have with the relatively small number of football players over several years, students want to be sure the coach will continue to be there. This means that a five-year or longer contract is necessary to help convince potential students that the coach who recruited them will remain at the school for their entire undergraduate terms, usually four or five years. College presidents, on the other hand, do not have the same personal daily contact with students because the student body generally contains thousands of undergraduates, and the college president will have limited time to spend with any of them. Most college presidents are largely focused on fundraising and administrative duties, often not even teaching any classes.

A third potential explanation for the differences in contract length is the close relationship between most college presidents and the university trustees that are ultimately charged with managing the school. Many trustees are large donors to the university that have been recruited to join the board of trustees by the college president. They work closely with college presidents in a variety of roles and are generally dependent on college presidents for almost all of the information that they have about the school. Not surprisingly, this leads to a comfortable, friendly relationship between the board of trustees and college presidents; one where there is not a constant threat of termination. Ultimately, this relationship limits the need for strong legal protections, such as a fixed, long-term employment contract.

Football coaches, on the other hand, are judged on their win-loss record every season. Even a well-established coach that has a mediocre year or two may find himself out of a job. ${ }^{210}$ Coaches cannot rely solely on close connections to boosters, or trustees, to keep them employed if their teams fail to meet the generally very high expectations of alumni and others. As a result, they bargain for longer, fixed-term contracts to protect themselves in the event of termination.

208. Coaches are generally paid for the remaining years of their contracts when they are terminated without cause. Thomas \& Van Horn, supra note 50, at 235. For further discussion of termination without cause, see infra Section III.D.3.

209. Thomas \& Van Horn, supra note 50, at 228.

210. This was demonstrated recently when the University of Georgia fired its very successful football coach for not winning enough big games. Mark Schlabach, Mark Richt Out at Georgia, ESPN (Nov. 30, 2015), http://espn.go.com/collegefootball/story/_id/14249377/mark-richt-fired-coach-georgia-bulldogs ("Richt had the fifthbest winning percentage among active FBS coaches"). 


\section{Termination Provisions: With Cause and Without Cause}

Longer fixed-term contracts are only part of the way that employees protect their economic interests in the event that they are terminated. But as any labor lawyer knows, having a long-term employment contract does not guarantee that you will be employed for the full term. "A president's eventual departure may result from an agreed-upon schedule; board dissatisfaction with the president's performance or the president's with the board's; retirement, disability, or death; interest in an outside opportunity; or some combination of these reasons." 211 Even if the president performs well, the board retains the ability to breach the contract and terminate employees, although it may be liable for damages arising from the breach.

The amount of damages paid depends on whether the employee was terminated with or without cause. Termination with cause occurs when the employee commits a bad act or harmful omission that is defined in the employment contract as constituting grounds for-cause termination. As a result, most employment contracts contain very carefully drafted definitions for what cause means. An employee that breaches an employment contract for cause will normally receive no severance compensation. ${ }^{212}$

By comparison, an employee that is terminated without cause is frequently entitled to contractually specified severance payments or, alternatively, to commonlaw damages for breach, often equal to the full amount of all the compensation that the employee would have been entitled to if the contract had been fully performed. ${ }^{213}$ In other words, "Severance pay is common when a board chooses to end the contract without showing cause before the end of the contract's term."214

Clearly, it is preferable from the employee's perspective to be terminated without cause than to be fired for cause. For these reasons, counsel for top employees will strongly resist including strong definitions of cause in their clients' employment contracts. ${ }^{215}$ All of these same considerations apply at universities. ${ }^{216}$

211. JOHNSTON \& FERRARE, supra note 59, at 131

212. See Stewart J. Schwab \& Randall S. Thomas, An Empirical Analysis of CEO Employment Contracts: What Do Top Executives Bargain For?, 63 WASH. \& LEE L. REV. 231, 237-38 (2006).

213. In re Walt Disney Co. Derivative Litig., 906 A.2d 27, 35 (Del. 2006) (ruling that a former employee was entitled to $\$ 130$ million in severance payments after he was fired without cause). In many circumstances, the employee would still have a duty to mitigate the employer's damages by seeking alternative employment. Frye v. Memphis State Univ., 806 S.W.2d 170, 173 (Tenn. 1991) (stating that when an employee is wrongfully terminated he "is only required to exercise reasonable diligence in seeking other employment of a similar or comparable nature").

214. ATWELL \& WELLMAN, supra note 12, at 42.

215. See Schwab \& Thomas, supra note 211, at 238.

216. Stated differently:

The board needs to know, after a period of initial acceptance has passed, that the new president will not desert on short notice, and the president needs assurance that he or she will be given reasonable leave with salary if circumstances require a change. Further, the absence of clear termination arrangements after a presidential tenure has reached a 


\section{For-Cause Termination Clauses}

From a university's point of view, for-cause termination provisions are an important protection from the damage to its reputation and image that could arise if a college president or football coach engages in serious misconduct. ${ }^{217}$ By carefully enumerating a series of offenses that will trigger for-cause termination, the university can try to deter or, if unsuccessful, to punish the offenders for their actions. The complete loss of all severance pay is a significant deterrent to most high-level employees, such as college presidents or football coaches. There is also likely to be severe reputational harm to the employee who is terminated for cause.

Given these harsh penalties, a college president, or football coach, will negotiate aggressively to limit the definition of what constitutes cause in the employment contract. Table 7A provides a breakdown of all of the defined terms that constitute grounds for for-cause terminations with the data showing the percentage of college president employment contracts in the full sample that contain the particular provisions. ${ }^{218}$

reasonable length can lead to lawsuits, which are expensive and

damaging to the institution.

NEFF \& LEONDAR, supra note 58, at 81 .

217. Some commentators have argued that football coaches have been involved in far too many instances of serious misconduct. See, e.g. Pete Volk \& Jason Kirk, The Bobby Petrino Controversy Timeline: A Decade of Shenanigans, SB NaTION (Aug. 11, 2016, 11:35 AM), http://www.sbnation.com/college-football/2014/1/9/5288648/bobby-petrinolouisville-scandal-timeline.

218. As these contracts often contain multiple terms, the numbers shown in the table do not sum to $100 \%$. 


\begin{tabular}{|c|c|}
\hline For-Cause Provision & $\begin{array}{c}\text { Percentage of Contracts } \\
\text { Containing Provision }\end{array}$ \\
\hline Gross Misconduct & $6.4 \%$ \\
\hline Unprofessional Conduct & $19.0 \%$ \\
\hline Neglect of Duties & $18.4 \%$ \\
\hline Breach of Contract & $14.5 \%$ \\
\hline Felony & $13.3 \%$ \\
\hline Moral Turpitude & $22.9 \%$ \\
\hline Fraud & $17.7 \%$ \\
\hline Violation of College Policies & $15.0 \%$ \\
\hline Violation of Ethical Standards & $1.6 \%$ \\
\hline Gambling & $0.0 \%$ \\
\hline Substance Abuse & $3.4 \%$ \\
\hline Conflict of Interest & $0.0 \%$ \\
\hline Drug Test Program Failure & $0.0 \%$ \\
\hline Absence from Work & $8.8 \%$ \\
\hline
\end{tabular}

Table 7A: College President For-Cause Termination Provisions ${ }^{219}$

219. For the college president employment contracts, we used the following definitions: Gross Misconduct was coded if the contract listed it as grounds for termination with cause. Unprofessional Conduct was coded if the contract listed unprofessional behavior or other conduct that reflects negatively upon the university as grounds for termination with cause. Neglect of Duties was coded if the contract had provisions that stated that neglect of duties, failure to perform duties, inability to perform duties, or absence from duties constituted grounds for termination with cause. Breach of Contract was coded if the contract stated that a breach of the employment contract was grounds for termination with cause. Felony was coded if the contract stated that the conviction of a crime constituting a felony was grounds for termination with cause. Moral Turpitude was coded if the contract stated that the conviction of a crime involving moral turpitude, or any other provision relating to moral turpitude-including things such as violation of antidiscrimination policies or sexual harassment - was grounds for termination for cause. Fraud was coded if the contract listed either fraud or dishonesty as grounds for termination with cause. Violation of College Policies was coded if the contract that the violation of college policy, constitution, by-laws; failure by president to respond promptly and accurately to any violation that materially adversely affects the school; violation of any federal, state or local law, regulation, ordinance or constitutional provision (non-felony related) for termination with cause. Violation of Ethical Standards was coded if the contract stated that the violation of an ethics standard was grounds for termination with cause. Gambling was coded if the contract listed gambling or betting of any kind as grounds for termination with cause. Substance abuse was coded if the contract listed substance abuse of any kind as grounds for termination with cause. Conflict of Interest was coded if the contract listed a conflict of interest as grounds for termination with cause. Drug Test Program Failure was coded if the contract listed failure to cooperate in the enforcement and implementation of any drug testing program as grounds for termination with cause. 
The most interesting feature of this table is how infrequently many of these terms appear in the college president employment contracts. The most common forcause termination provision is moral turpitude, which shows up in about one-quarter of the contracts, ${ }^{220}$ followed closely by unprofessional conduct, neglect of duties, fraud, violation of college policies, breach of contract, and commission of a felony, all of which occur in between 13 and $19 \%$ of the contracts. In contrast, gambling, failing a drug test, and acting with a conflict of interest are not included in any of the college president contracts as grounds of for-cause termination. In fact, as explored more fully in Table 9A, during the 2008-2014 time period almost twothirds of college president contracts did not contain for-cause termination provisions at all.

The contrast with college football coach contracts is stark. Table 7B shows that in our full sample more than $80 \%$ of all college football coach contracts have for-cause termination provisions that include gross misconduct, neglect of duties, and violations of NCAA rules. In addition, unprofessional conduct, breach of contract, and moral turpitude show up in between $50-60 \%$ of all football coach contracts. All of the remaining terms appeared less frequently, although most are in the double-digit percentages of contracts. In comparison to college president agreements, during the 2008-2013 time period only a tiny fraction $(3.23 \%)$ of football coach employment contracts did not contain a for-cause termination clause. Plainly, football coaches are much more likely than college presidents to have strong contractual language in their agreements defining the grounds of for-cause termination.

Absence was coded if the contract stated that a prolonged absence-possibly due to illness or disability - was grounds for termination with cause.

220. Moral turpitude has been defined as an "act or behavior that gravely violates moral sentiment or accepted moral standards of a community and is a morally culpable quality held to be present in some criminal offenses as distinguished from others." Moral Turpitude, BLACK's LAW DiCTIONARY (5th ed. 1979). 


\begin{tabular}{|c|c|}
\hline Provision & $\begin{array}{c}\text { Percentage of Contracts } \\
\text { Containing Provision }\end{array}$ \\
\hline Gross Misconduct & $85 \%$ \\
\hline Unprofessional Conduct & $65.4 \%$ \\
\hline Neglect of Duties & $82.3 \%$ \\
\hline Breach of Contract & $60.8 \%$ \\
\hline Felony & $31.1 \%$ \\
\hline Moral Turpitude & $50.5 \%$ \\
\hline Fraud & $30.5 \%$ \\
\hline Violation of NCAA rules & $93.1 \%$ \\
\hline Gambling & $11.7 \%$ \\
\hline Substance Abuse & $15.1 \%$ \\
\hline Conflict of Interest & $4.6 \%$ \\
\hline Drug Test Program Failure & $7.7 \%$ \\
\hline
\end{tabular}

Table 7B: Football Coaches For-Cause Termination Provisions (Percentage of Contracts) 221

The unique nature of the coaches' job helps explain the difference between football coaches' and college presidents' for-cause-termination provisions. For

221. For the college football coach employment contracts, we used the following definitions: Gross misconduct was coded if the contract listed it as grounds for termination with cause. Unprofessional conduct was coded if the contract listed unprofessional behavior or other conduct that reflects negatively upon the university as grounds for termination with cause. Neglect of Duties was coded if the contract had provisions that stated that neglect of duties, failure to perform duties, inability to perform duties, or absence from duties constituted grounds for termination with cause. Breach of Contract was coded if the contract stated that a breach of the employment contract was grounds for termination with cause. Felony was coded if the contract stated that the conviction of a crime constituting a felony was grounds for termination with cause. Moral Turpitude was coded if the contract stated that the conviction of a crime involving moral turpitude, or any other provision relating to moral turpitude-including things such as violation of antidiscrimination policies or sexual harassment-was grounds for termination for cause. Fraud was coded if the contract listed either fraud or dishonesty as grounds for termination with cause. Violation of NCAA rules was coded if the contract listed a violation of NCAA, conference, or university rules; the failure to report a violation of NCAA, conference, or university rules; counseling those under the coach's supervision to fail to respond promptly and accurately to any NCAA, conference, university, or other official inquiry; or the coach's failure to respond promptly and accurately to any NCAA, conference, university, or other official inquiry as grounds for termination with cause. Gambling was coded if the contract listed gambling or betting of any kind as grounds for termination with cause. Substance Abuse was coded if the contract listed substance abuse of any kind as grounds for termination with cause. Conflict of Interest was coded if the contract listed a conflict of interest as grounds for termination with cause. Drug Test Program Failure was coded if the contract listed failure to cooperate in the enforcement and implementation of any drug testing program as grounds for termination with cause. 
example, in football coach contracts a violation of NCAA rules will invariably be included as a grounds for termination, whereas there is no equivalent set of obligations for college presidents. Gambling by a coach is also grounds for termination, which most likely reflects concerns about coaches betting on sports games. The remaining differences may be the result of the relatively high likelihood of termination and corresponding damage to the future employability of the football coach. Coaches may also wind up in scandals more often than presidents. ${ }^{222}$ University presidents are fired by their home schools much less frequently. ${ }^{223}$ Thus, there may be less need to contractually lay out cause-termination provisions for college presidents.

\section{Evolution of Cause Termination Provisions}

A related issue is how the use of the various defined terms of for-cause termination has evolved over time. Table $8 \mathrm{~A}$ displays these changes over three time periods: $1995-2001,2002-2007$, and 2008-2014. In every case except one, ${ }^{224}$ each clause was used at an equal or greater frequency. ${ }^{225}$ This strongly suggests that college president employment contracts are moving in the direction of including more terms in the definition of for-cause termination and increasing their protection of the university's interests.

222. See, e.g., Top 10 Coaching Scandals in College Sports History, OnLINE U. BLOG (Apr. 6, 2010), http://www.sbnation.com/college-football/2014/1/9/5288648/bobbypetrino-louisville-scandal-timeline; Volk \& Kirk, supra note 217.

223. See supra Section III.A (comparing average tenure of college presidents and football coaches); see also Am. COUNCIL ON EdUC., The AMERICAN COLlEge Presdent 5 Tb1.2 (2012); see also What is the Average Tenure of a College or University President, Ass'N GOVERNING BOARDS, http://agb.org/faq/what-is-the-average-tenure-of-a-college-oruniversity-president (last visited October 27, 2016) (stating that the average length a college president serves is seven years).

224. The one exception is violation of ethical standards, which declined from 19952001 to 2002-2007, but then increased in the final time period.

225. Gambling, conflict of interest, and drug-test-program failure did not appear in any college president contracts over the entire sample period. 


\begin{tabular}{|c|c|c|c|}
\hline Defined Term & $\mathbf{1 9 9 5 - 2 0 0 1}$ & $\mathbf{2 0 0 2 - 2 0 0 7}$ & $\mathbf{2 0 0 8 - 2 0 1 4}$ \\
\hline Gross Misconduct & $0.0 \%$ & $5.0 \%$ & $10.0 \%$ \\
\hline Unprofessional Conduct & $9.8 \%$ & $17.3 \%$ & $24.2 \%$ \\
\hline Neglect of Duties & $7.3 \%$ & $16.3 \%$ & $24.6 \%$ \\
\hline Breach of Contract & $6.1 \%$ & $9.9 \%$ & $21.6 \%$ \\
\hline Felony & $3.7 \%$ & $12.9 \%$ & $17.4 \%$ \\
\hline Moral Turpitude & $13.4 \%$ & $21.3 \%$ & $28.6 \%$ \\
\hline Fraud & $2.4 \%$ & $17.8 \%$ & $23.5 \%$ \\
\hline Violation of College Policy & $12.2 \%$ & $14.4 \%$ & $17.3 \%$ \\
\hline Violation of Ethical Standards & $6.1 \%$ & $0.5 \%$ & $1.2 \%$ \\
\hline Gambling & $0.0 \%$ & $0.0 \%$ & $0.0 \%$ \\
\hline Substance Abuse & $0.0 \%$ & $3.5 \%$ & $4.6 \%$ \\
\hline Conflict of Interest & $0.0 \%$ & $0.0 \%$ & $0.0 \%$ \\
\hline Drug Test Program Failure & $0.0 \%$ & $0.0 \%$ & $0.0 \%$ \\
\hline Absence from Work & $7.3 \%$ & $7.9 \%$ & $10.4 \%$ \\
\hline
\end{tabular}

Table 8A: College President For-Cause Termination Provisions over Time (Percentages)

The same trends can be seen in the data for football coach contracts shown in Table 8B. When we compare the frequency of for-cause terms in 1995-2001 with their usage in 2008-2013, we see that every single category has become more common over time. For example, in the most recent time period, breach of contract and unprofessional conduct appear in roughly $70 \%$ of all college football coach employment contracts as a ground for termination. 


\begin{tabular}{|c|c|c|c|}
\hline Defined T erm & $\mathbf{1 9 9 5 - 2 0 0 1}$ & $\mathbf{2 0 0 2 - 2 0 0 7}$ & $\mathbf{2 0 0 8}-\mathbf{2 0 1 3}$ \\
\hline Neglect of Duties & $72.5 \%$ & $84.8 \%$ & $87.6 \%$ \\
\hline Breach of Contract & $47.2 \%$ & $65.2 \%$ & $67.1 \%$ \\
\hline Felony & $22.8 \%$ & $30.2 \%$ & $38.8 \%$ \\
\hline Moral Turpitude & $48.7 \%$ & $47.3 \%$ & $56.1 \%$ \\
\hline Fraud & $14.0 \%$ & $29.6 \%$ & $42.6 \%$ \\
\hline Unprofessional Conduct & $54.9 \%$ & $64.3 \%$ & $72.5 \%$ \\
\hline Violation of NCAA Rules & $87.0 \%$ & $94.2 \%$ & $96.5 \%$ \\
\hline Gambling & $2.6 \%$ & $11.0 \%$ & $17.8 \%$ \\
\hline Substance Abuse & $5.2 \%$ & $13.1 \%$ & $23.2 \%$ \\
\hline Conflict of Interest & $2.6 \%$ & $4.3 \%$ & $5.4 \%$ \\
\hline Drug-Test-Program Failure & $0.5 \%$ & $6.7 \%$ & $12.7 \%$ \\
\hline Gross Misconduct & $0.0 \%$ & $0.6 \%$ & $1.6 \%$ \\
\hline
\end{tabular}

Table 8B: Football Coach For-Cause Termination Provisions over Time (Percentage of Contracts)

Finally, we examine the change in the number of defined terms that are contained in the definition of what is considered cause in our employment contracts. Table 9A illustrates the trend of the number of for-cause termination terms in college president contracts over the same time periods as previously discussed. The first row shows that a large majority of these contracts contained no for-cause termination provisions, although this percentage has declined over time. However, even in the most recent time period (2008-2014), 66.09\% of college president contracts do not contain for-cause termination provisions. The contracts in the next-largest category $(10.03 \%)$ during that time period, include six defined terms in their definition of cause. Generally speaking, there is a strong trend toward having more enumerated terms in the cause definitions of these agreements. 


\begin{tabular}{|c|c|c|c|}
\hline $\begin{array}{c}\text { Number of } \\
\text { Cause Termination } \\
\text { Provisions }\end{array}$ & $\mathbf{1 9 9 5 - 2 0 0 1}$ & $\mathbf{2 0 0 2 - 2 0 0 7}$ & $\mathbf{2 0 0 8 - 2 0 1 4}$ \\
\hline 0 & $81.14 \%$ & $73.46 \%$ & $66.09 \%$ \\
\hline 1 & $4.76 \%$ & $1.90 \%$ & $3.46 \%$ \\
\hline 2 & $0 \%$ & $0.47 \%$ & $0 \%$ \\
\hline 3 & $1.19 \%$ & $3.79 \%$ & $0.69 \%$ \\
\hline 4 & $5.95 \%$ & $4.27 \%$ & $4.15 \%$ \\
\hline 5 & $1.19 \%$ & $7.11 \%$ & $7.27 \%$ \\
\hline 6 & $4.76 \%$ & $5.69 \%$ & $10.03 \%$ \\
\hline 7 & $0 \%$ & $2.84 \%$ & $5.88 \%$ \\
\hline 8 & $0 \%$ & $0.47 \%$ & $2.08 \%$ \\
\hline 9 & $0 \%$ & $0 \%$ & $.35 \%$ \\
\hline
\end{tabular}

Table 9A: Evolution of the Number of For-Cause Termination Clauses in College President Contracts (Percentage of Contracts)

We were interested to see whether the change in the number of for-cause termination definitions over time is statistically significant. In order to make this determination, we calculated a chi-squared statistic. ${ }^{26}$ We found that the value of the chi-squared statistic is 39.17 , which is statistically significant at less than the $1 \%$ level of significance. This is consistent with the claim that college president employment contracts have shown an increased number of for-cause termination provisions over the course of our sample period.

A similar trend, albeit at a much higher level, can be seen in the football coach contracts. The percentage of contracts without for-cause termination provisions drops steadily from $12.95 \%$ at the beginning of the sample period to $3.23 \%$ at the end of the sample period. Moreover, for contracts with the highest number of listed terms per contract, the percentage of contracts increased during the sample period.

226. See generally Priscilla E. GREEnwood \& Michael S. Nikulin, A Guide to ChI-Squared TESTING (1996) (stating that a chi-squared statistic helps a researcher test the "goodness-of-fit" of a data distribution). 


\begin{tabular}{|c|c|c|c|}
\hline $\begin{array}{c}\text { Number of For-Cause } \\
\text { Termination provisions }\end{array}$ & $\mathbf{1 9 9 5 - 2 0 0 1}$ & $\mathbf{2 0 0 2}-\mathbf{2 0 0 7}$ & $\mathbf{2 0 0 8}-\mathbf{2 0 1 3}$ \\
\hline 0 & $12.95 \%$ & $5.79 \%$ & $3.23 \%$ \\
\hline 1 & $6.74 \%$ & $5.49 \%$ & $3.50 \%$ \\
\hline 2 & $6.74 \%$ & $1.22 \%$ & $1.35 \%$ \\
\hline 3 & $6.22 \%$ & $10.98 \%$ & $10.78 \%$ \\
\hline 4 & $32.64 \%$ & $26.83 \%$ & $19.95 \%$ \\
\hline 5 & $26.94 \%$ & $25.30 \%$ & $21.02 \%$ \\
\hline 6 & $3.63 \%$ & $6.71 \%$ & $12.67 \%$ \\
\hline 7 & $1.55 \%$ & $7.93 \%$ & $11.32 \%$ \\
\hline 8 & $2.07 \%$ & $7.32 \%$ & $7.55 \%$ \\
\hline 9 & $0.52 \%$ & $2.13 \%$ & $5.66 \%$ \\
\hline 10 & $0 \%$ & $0.30 \%$ & $1.89 \%$ \\
\hline 12 & $0 \%$ & $0 \%$ & $1.08 \%$ \\
\hline
\end{tabular}

Table 9B: Football Coaches Evolution of Number of For-Cause Termination Clauses (Percentage of Contracts)

To test the significance of these changes over time, we calculated a chisquared statistic. ${ }^{227}$ We found that it has a value of 116.14 , which is significant at less than the $1 \%$ level of significance. This is strong evidence that the number of defined terms in the for-cause termination provisions in all college football coach contracts has increased over time.

Why are there more terms in the for-cause termination definitions for these coaches and college presidents over time? One possibility is that the cost to the school of bad behavior by top executives, particularly by football coaches, ${ }^{228}$ has increased over time with the larger revenues generated by the sport. ${ }^{229}$ Schools are likely more attentive to the reasons for football coaches' forced departures, especially because they have to pay large severances to football coaches that are terminated without cause. 230

Another explanation may be that the increased professionalization of the hiring process has resulted in schools standardizing the contract language in an effort to protect themselves. As discussed in Part II, the hiring process for college presidents and football coaches increasingly involves executive search firms and agents, at least for football coaches. Combined with the greater use of benchmarking for compensation and contract terms, this contracting process may have encouraged

227. For further information about chi-squared statistics, see generally id.

228. Volk \& Kirk, supra note 217.

229. NCAA, Eleven-Year Trends in Division 1 Athletics Finances 12 (Sept. 2015), http://www.ncaa.org/sites/default/files/DivisionI_ElevenYearFinances-20150917.pdf (stating median total revenues have increased by $120.7 \%$ from 2004 to 2014).

230. Hobson \& Rich, supra note 57. 
universities to include stronger contractual language in their top executives' employment contracts.

\section{Without-Cause Termination Payments}

There are good reasons why schools may prefer to terminate an executive without cause. "Termination without cause, from the board's point of view, is often the cleanest basis for separation from employment, allowing the removal of a problematic incumbent without the details having to be made public." 231 When college presidents or football coaches are terminated without cause by their schools, they may be entitled under the terms of their employment contracts to receive severance payments.

How frequently do these top employees receive such payments and how has that changed over time? We begin with an analysis of college presidents' employment contracts. Table 10A shows the percentages of college president contracts containing without-cause termination provisions and how the likelihood of such clauses appearing in these agreements has changed over our sample period.

\begin{tabular}{|c|c|c|c|}
\hline $\begin{array}{c}\text { Without-Cause } \\
\text { Termination Payments }\end{array}$ & $\mathbf{1 9 9 5 - 2 0 0 1}$ & $\mathbf{2 0 0 2}-\mathbf{2 0 0 7}$ & $\mathbf{2 0 0 8 - 2 0 1 4}$ \\
\hline No & $90.12 \%$ & $74.63 \%$ & $71.43 \%$ \\
\hline Yes & $9.88 \%$ & $23.38 \%$ & $28.19 \%$ \\
\hline
\end{tabular}

Table 10A: College President Without-Cause Termination Payments (Percentage of Contracts)

Surprisingly, over the entire sample period, a substantial majority (108 agreements or approximately $80 \%$ of the sample) of college president employment contracts do not include any provision for the payment of severance compensation in a without-cause termination. By contrast, in 2008-2014, Table 10B shows that over $83 \%$ of coaches do have such provisions in their agreements. Equally interesting, the percentage of college president contracts with such provisions has increased significantly over that same period. While only about $10 \%$ had such clauses in the 1995-2001 time period, by 2008-2014 roughly $29 \%$ of college presidents' contracts included such without-cause termination payments. A similar trend toward greater use of without-cause termination payments for football coaches is evident in Table 10B. 


\begin{tabular}{|c|c|c|c|}
\hline $\begin{array}{c}\text { Without-Cause } \\
\text { Termination Payments }\end{array}$ & $\mathbf{1 9 9 5 - 2 0 0 1}$ & $\mathbf{2 0 0 2 - 2 0 0 7}$ & $\mathbf{2 0 0 8 - 2 0 1 3}$ \\
\hline No & $41.97 \%$ & $29.57 \%$ & $16.17 \%$ \\
\hline Yes & $58.03 \%$ & $70.43 \%$ & $83.83 \%$ \\
\hline
\end{tabular}

Table 10B: Football Coach Without-Cause Termination Payments (Percentage of Contracts)

In addition, we note that only a handful of college president employment contracts contain provisions that require presidents to mitigate damages paid by the school if they were terminated without cause. ${ }^{232}$ By comparison, roughly one-third of the football coach contracts in our sample require a departing coach to mitigate his damages. ${ }^{233}$ Sometimes, the same school will treat these employees differently. For instance, Mark Helfrich, Oregon's football coach, had a mitigation clause in his contract, while Michael Gottfredson, Oregon's president, had no mitigation clause in his contract. ${ }^{234}$

For those contracts that contain without-cause termination severance provisions, Table 11 illustrates the distribution of payments provided for in these employment agreements. For football coaches, we see that over two-thirds provide for a minimum of three-years-base salary, while almost one-third pay more than five years of base salary. By comparison, for college presidents, the mean level of these payments is 1.69 years of base salary, which is much lower than for the football coaches. As demonstrated by the table, college presidents rarely receive payments of more than three years of their base salary.

232. We found a total of eight college president contracts in our sample that contained mitigation clauses. Adam Herbert's 2003 contract with Indiana University is typical of these agreements. Section V, paragraph 4 states: "In the event the President is terminated without cause and does not return to the tenured faculty position, the President agrees to mitigate the University's obligation to continue the payments set forth in this section by making reasonable and diligent efforts to obtain new employment." Employment Agreement Between the Trustees of Ind. Univ. and Adam Herbert, President, Ind. Univ. §V (June 5, 2003) (on file with author).

233. Thomas \& Van Horn, supra note 50, at 235.

234. Compare Employment Agreement Between the Univ. of Or. and Mark Helfrich, Head Coach, Univ. or Or. Intercollegiate Football Team §6.2(e) (Jan. 20, 2013) (on file with author), with Employment Agreement and Notice of Appointment Between the Or. State Bd. of Higher Educ. and Dr. Michael Gottfredson, President, Univ. of Or. (Aug. 1, 2012) (on file with author) (No mitigation clause). 


\begin{tabular}{|c|c|c|}
\hline Payments & $\begin{array}{c}\text { Coaches (\% Base } \\
\text { Salary) }\end{array}$ & $\begin{array}{c}\text { Presidents ( } \% \text { Base } \\
\text { Salary) }\end{array}$ \\
\hline Payment = 0 & $12.5 \%$ & $82.09 \%$ \\
\hline $0<$ Payment < 1 Year & $1.6 \%$ & $2.16 \%$ \\
\hline Payment = 1 Year & $2.0 \%$ & $9.12 \%$ \\
\hline $1<$ Payment < 2 Year & $5.2 \%$ & $1.66 \%$ \\
\hline Payment = 2 Year & $2.3 \%$ & $1.33 \%$ \\
\hline $2<$ Payment < 3 Year & $5.9 \%$ & $.66 \%$ \\
\hline Payment = 3 Year & $3.3 \%$ & $1.33 \%$ \\
\hline $3<$ Payment < 4 Year & $8.8 \%$ & $.17 \%$ \\
\hline Payment = 4 Year & $5.9 \%$ & $.17 \%$ \\
\hline $4<$ Payment < 5 Year & $11.9 \%$ & $0 \%$ \\
\hline Payment = 5 Year & $11.5 \%$ & $.33 \%$ \\
\hline Payment > 5 Year & $29.0 \%$ & $1.0 \%$ \\
\hline Not Mentioned or Other Form & $0 \%$ & $0 \%$ \\
\hline
\end{tabular}

Table 11: Comparison of Without-Cause Termination Payments for College Presidents and Football Coaches (Percentages of Base Salary)

A possible explanation for the football coaches' larger severance payments is their increased likelihood of termination. The average coach's short job tenure encourages stronger upfront negotiations on what happens to the parties when the coach leaves either voluntarily or involuntarily. Short job tenure means coaches have a greater need for compensation for the increased risk of financial harm, which may result from being fired without cause.

Relatedly, some top employees may be required to make payments to their employer if they choose to resign from their position without providing an enumerated "good reason" for their action. ${ }^{235}$ If a coach is highly successful, the hiring university tries to prevent him from leaving too easily by increasing "switching costs" for the university that lures him away. Basically, the hiring university will negotiate to include contractual language that requires the voluntarily departing coach (and indirectly the coach's new school) to make substantial contract buyout payments if the coach leaves. ${ }^{236}$

235. For CEOs, good reason for quitting is commonly defined to include the CEO getting paid less, being transferred to a distant location, or being forced to take on less job responsibility. Schwab \& Thomas, supra note 211, at 253.

236. In our earlier work, we found that approximately $37 \%$ of coaches owe payments to their former employer if they leave their current coaching position upon any without-cause resignation, while an additional $47 \%$ of coaches owe a payment for any without-cause resignation only if they are accepting a position at another university. Where no buyout clause is included in the contract, universities typically allow the coach to depart without seeking damages for the harm caused by his departure. Thomas \& Van Horn, supra 
But no college president is required to make any payment if they resign without good reason, even if they do so to accept another position as the president of another university. In addition, many college presidents negotiate to receive a tenured position at their school as part of their incoming compensation package. This means that they automatically have a fallback job in the event that they are terminated by their university from their position as president.

\section{E. Noncompetition and Arbitration Provisions}

Noncompetition agreements and arbitration clauses are frequently employed by public corporations. ${ }^{237}$ Companies prefer noncompetition agreements because they provide significant protection against key employees walking away from the firm with sensitive information and working for competing businesses. ${ }^{238}$ Arbitration provisions require employees to litigate employment disputes in private rather than use the courts. Both types of provisions are common in CEO employment contracts. $^{239}$

There is little evidence that noncompetition clauses are employed in either college president or football coach contracts. In our sample, only two college president contracts include noncompetition clauses: John Dunn's 2012 contract with Western Michigan ${ }^{240}$ and Mark Schlissel's 2014 contract with Michigan. ${ }^{241}$ In our prior work, only 23 contracts out of the 429 football coaches in our sample employed noncompetition provisions. ${ }^{242}$ It seems likely that football coaches would be opposed to having such clauses in their contracts. Their concern would be that a broad noncompetition clause would stop them from being able to engage in future coaching positions.

More generally, it seems likely that both types of top employees have skills that are less firm-specific and involve less-confidential information than those of CEOs. In other words, the university may have less concern that a college president or football coach will be able to remove sensitive information to another university and be able to compete with their former employer unfairly, than a company may have if its CEO did the same thing.

In a related vein, CEO employment contracts often include arbitration clauses because, in that setting, both parties prefer private resolution of their

note 50, at 237. See generally Martin J. Greenberg, College Coaching Contracts Revisited: A Practical Perspective, 12 MARQ. SPORTS L. REV. 127, 234 (2001) (discussing buyout provisions).

237. Norman D. Bishara et al., An Empirical Analysis of Noncompetition Clauses and Other Restrictive Postemployment Covenants, 68 VAND. L. REV. 1, 28 (2015) (finding that $80 \%$ of contracts contain covenants not to compete); see also Thomas et al., supra note 165 , at 981 (finding that $50 \%$ of CEO employment contracts during a ten-year period contained arbitration clauses).

238. See Bishara et al., supra note 237, at 12 .

239. Id. at 45 n.174.

240. See Employment Agreement Between W. Univ. Bd. of Trustees and Dr. John M. Dunn, art. 8 (Dec. 17, 2012) (on file with author).

241. See Employment Agreement Between Univ. of Mich. and Dr. Mark S. Schlissel $§ 12$ (Jan. 24, 2014) (on file with author).

242. Thomas \& Van Horn, supra note 50, at 238. 
disputes. ${ }^{243}$ In our samples, arbitration provisions appear in only a minority of these top employees' agreements, ${ }^{244}$ although they are more common than noncompetition clauses. For example, there are 26 college president contracts that contain arbitration provisions. Football coaches are more likely to have arbitration provisions: we found such provisions in $11.4 \%$ of football coach contracts. ${ }^{245}$ Placing mandatory arbitration provisions in football coach contracts has been suggested in order to avoid the "spotlight of a courtroom," as quarrels between football coaches and their schools are media-worthy events. ${ }^{246}$ However, according to our research, this advice has not gained in popularity.

\section{CONCLUSION}

University football coaches and college presidents are highly paid executives. In this Article, we argue that they are highly skilled individuals who have great responsibility for their programs and universities, and that given competitive labor markets, there is little reason to believe that their level of compensation is inefficient. In support of our position, we analyzed their compensation packages and written employment contracts and compared them over a wide variety of characteristics. Our observations are generally consistent with economic theory.

We find several noteworthy results. First, football coaches have much shorter tenure than college presidents, which has significant implications for the structure of their contracts. For example, football coaches have a greater need for protection against termination without cause and as a result, have more frequent and larger severance pay provisions in their contracts.

Second, football coach pay has been rising much more quickly over recent years, especially at larger schools in the Power Five Conferences, in large part because of the explosion in television and bowl revenues for these football programs. Given the lucrative nature of college football, especially when the school's program is successful, there is a high degree of competition to attract the best coaches, and compensation levels have risen accordingly.

Third, college presidents' compensation is higher at larger schools and at the Power Five Conference schools, but the differences are much less dramatic. The

243. Id. at 239.

244. Recent litigation filed by former USC coach Steve Sarkisian against his former employer relating to the grounds for his termination may be sent to arbitration under the terms of his employment contract. Chip Patterson, USC Responds to Steve Sarkisian's Wrongful Termination Lawsuit, CBS SPORTS (Jan. 9, 2016), http://www.cbssports.com/collegefootball/eye-on-college-football/25443385/usc-respondsto-steve-sarkisian-wrongful-termination-lawsuit-contests-alcoholism.

245. Thomas \& Van Horn, supra note 50, at 238; see also Brent C. Moberg, Navigating the Public Relations Minefield: Mutual Protection Through Mandatory Arbitration Clauses in College Coaching Contracts, 16 J. LEGAL ASPECTS SPORT 85 passim (2006) (arguing that college football coaches should routinely include arbitration provisions).

246. Brent C. Moberg, Navigating the Public Relations Minefield: Mutual Protection Through Mandatory Arbitration Clauses in College Coaching Contracts, $16 \mathrm{~J}$. LEgAL AsPECTS SPORT 85, 86 (2006). The authors also suggest pairing a mandatory alternative dispute resolution clause with a confidentiality provision. Id. at 88 . 
relative difficulty in determining the metrics for measuring presidents' success and the lack of a major new source of revenue like television both seem to explain the relatively slow growth of college president pay.

Both sets of top university executives receive perquisites as part of their compensation, most of which are closely aligned with their ability to perform well in their positions. College presidents, for instance, are expected to entertain alumni regularly, and therefore are often provided with a suitable home by their school for doing so. Coaches, on the other hand, spend a lot of their time on the road recruiting high school athletes to come to their school, and are thus given cars and sometimes access to the university's plane.

Finally, turning to the legal terms of the employment contracts, we find that football coach contracts have much more specific terms than those of college presidents. In particular, we show that football coach contracts are more likely to include a fixed term of years for their employment, carefully written for-causetermination provisions, and substantial amounts of severance pay if they are terminated without cause. Each of these attributes is consistent with the differences arising from employment for the two types of employees with their home school. We also find that neither set of contracts makes significant use of arbitration or noncompetition clauses. 
